WORKING PAPER · NO. 2020-

\title{
An Analysis of Vice President Biden's Economic Agenda: The Long Run Impacts of Its Regulation, Taxes, and Spending
}

Timothy Fitzgerald, Kevin Hassett, Cody Kallen, and Casey B. Mulligan

OCTOBER 2020 


\title{
An Analysis of Vice President Biden's Economic Agenda: The Long Run Impacts of Its Regulation, Taxes, and Spending*
}

\author{
By Timothy Fitzgerald, Kevin Hassett, Cody Kallen, and Casey B. Mulligan
}

October 2020

\begin{abstract}
We estimate possible effects of Joe Biden's tax and regulatory agenda. We find that transportation and electricity will require more inputs to produce the same outputs due to ambitious plans to further cut the nation's carbon emissions, resulting in one or two percent less total factor productivity nationally. Second, we find that proposed changes to regulation as well as to the ACA increase labor wedges. Third, Biden's agenda increases average marginal tax rates on capital income. Assuming that the supply of capital is elastic in the long run to its aftertax return and that the substitution effect of wages on labor supply is nontrivial, we conclude that, in the long run, Biden's full agenda reduces full-time equivalent employment per person by about 3 percent, the capital stock per person by about 15 percent, real GDP per capita by more than 8 percent, and real consumption per household by about 7 percent.
\end{abstract}

\footnotetext{
${ }^{*}$ We appreciate discussions with John Cochrane as well as Jeremy Weber and other economists at the Council of Economic Advisers. Author affiliations are: Texas Tech University (Fitzgerald); The Lindsey Group and the Hoover Institution (Hassett); University of Wisconsin (Kallen); and University of Chicago, NBER, and the Committee to Unleash Prosperity (Mulligan).
} 


\section{Introduction}

Advancing equality, environmental protection and other social goals involves tradeoffs. The purpose of this paper is to quantify possible economic effects of the Biden agenda. Vice President Biden proposes to

- reverse some of the 2017 tax cuts as well as increase the taxation of corporations and high-income households and pass through entities;

- reverse much of the regulatory reform of the past three years as well as setting new environmental standards; and

- create or expand subsidies for, especially, health insurance and renewable energy.

The new regulations would affect resource usage by regulated industries while new taxes would distort the markets for capital and labor. We estimate that the full Biden agenda will reduce long-run real GDP per capita by more than 8 percent as a result of reducing full-time equivalent employment (FTEs) per person by 3 percent, the capital stock per person by 15 percent and total factor productivity by 2 percent. Relative to the CBO's 2030 projections for these variables (Congressional Budget Office 2020), this suggests there will be 4.9 million fewer employed individuals, \$2.6 trillion less GDP, and \$1.5 trillion less consumption in that year alone. Median household income in 2030 would be $\$ 6,500$ less.

Labor falls primarily due to new and high implicit taxes associated with more generous health insurance assistance delivered in the framework of the Affordable Care Act (ACA). The proposed regulations have two distinct effects. Some of them, especially the business regulations, redistribute from consumers to producers and thereby further reduce labor supply much like a markup or excise tax would. Other proposed regulations, such as those related to electricity generation and vehicle manufacturing, reduce total factor productivity (TFP). TFP affects real incomes and GDP while having offsetting income and substitution effects on aggregate labor supply.

Table 1 displays the policies whose effects we quantify. These policies include a dozen tax provisions. The combined effect of the tax provisions on the average marginal tax on capital 
income is calculated using a microsimulation model from the Open Source Policy Center. We find that the Biden plan includes many types of increases in taxes on capital income, which lower the incentive to invest. Among them, the most significant are an increase in the corporate rate, allowing bonus depreciation to expire, and increasing tax rates on pass through entities such as S-corporations, sole proprietorships, and partnerships.

Individual health insurance plans were subsidized by the Affordable Care Act, which Vice President Biden plans to expand. Because the subsidies are withheld on the basis of full-time employment, they are an implicit tax on full-time employment. Because they are also withheld on the basis of family income, they are also an implicit tax on income. We show how both of these implicit tax rates are increased by Biden's plans, primarily because the subsidies become more generous.

We model four significant green-energy policies. One of them uses mandates and subsidies to replace fossil fuels with renewable energy in electricity generation. Another requires the manufacturers of passenger vehicles to make them less reliant on fossil fuels. A third policy uses subsidies and mandates to increase electricity capacity to accommodate electric vehicles. Fourth, companies will be forced to pay financial damages commensurate with the amount they polluted in the past.

Finally, we assume that as president Biden will return to the regulatory path of the Obama administration, which includes reversing President Trump's reversals of Obama regulations. A class of regulations that has large economic impact are those that just prohibit certain kinds of products. Obama era health regulations prohibited low cost, high deductible, limited coverage health insurance plans, labeling them "junk." Obama-era telecommunications regulations (issued by the Federal Communications Commission) prohibited internet services that offered lower cost for lower speeds, or in return for greater user data, under the labels "net neutrality" and "protecting privacy." Forcing people to buy the highest quality and most expensive product, or none at all, lowers economic efficiency, or redistributes from consumers to the sellers of the expensive products, or both. 
Our conclusions about national aggregates are built up from the industry level where the legal obligations of new taxes and regulations are placed. ${ }^{1}$ The model reflects the supply and demand conditions for health insurance, automobiles, electricity, internet services, and much more. It also reflects the fact that industries compete with each other for workers, managers, investors, and capital. These markets clear at the same time that they are distorted by taxes and regulations that drive a "tax wedge" between their marginal social value in production and the marginal opportunity cost to their owners of supplying them. Taxes in our model are associated with government spending (we distinguish transfers from government purchases), and vice versa. Taxes, spending, or both have aggregate effects especially as they affect the marginal tax wedge. Redistribution tends to increase the spending of those who receive it while reducing the spending of those who finance it. In this way, we model Biden's plans for the federal government to spend on renewable energy, health insurance, the poor, and the unemployed.

The next step in our analysis is estimating how the agenda would affect total factor productivity, the marginal tax rate on capital income, and the labor wedge. These three effects are first estimated for subpopulations and then aggregated to the national level.

Treating the three national changes as changes in the parameters of the neoclassical growth model, we then estimate the long-run effects of the Biden agenda on full-time equivalent employment, capital accumulation, real GDP and real wages. In this model, a reduction in totalfactor productivity (TFP) reduces the marginal product of labor, and hence wages. However, such a wage change has little effect on overall employment or hours worked because of opposing income and substitution effects on labor supply. For similar reasons, capital-income taxes also have offsetting income and substitution effects on labor supply in the long run. People work less overall because the Biden agenda also increases marginal tax rates on work as it redistributes to the unemployed, low-income households, and producers in protected industries.

Table 2 shows the baseline and Biden-agenda tax and productivity parameters. Most of the additional labor (or consumption) taxation comes from changing rules for subsidizing ACA

\footnotetext{
${ }^{1}$ We are aware of thirteen economists who together concluded that "Biden's policies will result in economic growth that is faster, more robust, and more equitable." (Akerlof, et al. 2020) We have not yet been able to determine which policies they considered (their analog to our Table 1), whether they believe that the agenda increases or decreases marginal tax rates, or what quantitative model (if any) they used to weigh the various tradeoffs.
} 
plans. Regulation generates a labor wedge to the extent that it reduces competition. Because candidate Biden also promises to transform electricity generation without increasing retail electricity prices, subsidies will be needed, which we assume to be financed efficiently (a flatrate labor-income tax). Most of the TFP change from Vice President Biden's agenda comes from his plans for energy and vehicle manufacturing. The former requires a lot more input for each MWh of electricity output and the latter requires a lot more input for each unit of private value delivered to the consumer. In our model, all of the extra capital taxation coming from the Biden agenda is due to its various tax provisions.

Table 2 drives our quantitative results. Reducing the after-labor-tax share by 8 percent should reduce FTE employment by a couple of percent; we find about 3 percent with our elasticities. Reducing the after-capital-tax share by 16 percent should by itself reduce the capital-labor ratio by several percent; we find about 10 percent with our elasticities. The ratio is further reduced by the reduction in TFP so that the combined effect is to reduce it by 12 percent. The percentage change in GDP is essentially the TFP changes plus the factor-share weighted average of the labor and capital changes, which is a total reduction of more than 8 percent.

The combined effect of a portfolio of policies is different from the some of their individual effects. It matters whether a tax is introduced where there was none before, or on top of previous taxes. As another example, it matters whether converting electricity generation from fossil- to renewable-fuel source occurs in a world with electric cars or in a world with a mixed fleet. Our policy and macroeconomic framework allow us to consider these and other important interaction effects.

Section II of this paper provides the details of our conclusion, obtained with the open-source individual income and payroll tax Tax-Calculator microsimulation model from the Open Source Policy Center as well as open-source code to measure capital tax distortions to investment incentives, that Vice President Biden's agenda reduces the average marginal after-tax share of capital income by 16 percent. Our quantitative conclusion that this capital taxation by itself reduces long run wages by 3 percent is robust to many of our macroeconomic assumptions. 
Sections III and IV provide the details of our analysis of Vice President Biden's regulatory agenda. Although we quantify more than 20 regulations, they are dominated by two elements of his energy regulation agenda: electrifying the nation's fleet of passenger vehicles at the same time as taking offline generators powered by fossil fuels. Section V describes Vice President Biden's proposals to expand the ACA and how they increase marginal tax rates on labor income. Section VI and VII discuss trade policy and how the economy might transition to the long run. Section VIII concludes. 


\section{Capital taxation in the Biden agenda}

Our tax calculator and microsimulation model reflect the complexity of the tax laws in both the baseline and under Vice President Biden's policy. It also reflects the wide variety of tax situations that the nation's businesses find themselves in. Nevertheless, the complex calculations turn out to be dominated by a couple of simply understood pieces of arithmetic. One back-ofthe-envelope representation of our calculator begins with corporate business, whose investment is about 70 percent equity financed. In the baseline policy, the combination of bonus depreciation, expensing for research and development costs and section 179 make about 65 percent of corporate fixed assets eligible for expensing. Vice President Biden's policy would allow bonus depreciation to expire-reducing the expensing rate to 10 percent of assets-and would tax the profits from such investment with a 28 percent statutory rate. In other words, 55 percent of corporate investment goes from being largely protected from federal taxation to being taxed at a 28 percent rate. Even if this had no effect on the incentives for debt-financed investment, the expensing changes add about 11 percentage points to the average marginal rate on corporate investment, which is close to the results shown below from the calculator. ${ }^{2}$ In addition, a significant fraction of corporate owners would be subject to Vice President Biden's additions to personal tax rates on dividend income and capital gains, which brings the total addition to the average marginal rate for corporations to 13 percentage points.

As another example, consider pass-through business, which employ 43 percent of workers (United States Census Bureau 2019). ${ }^{3}$ The majority of pass-through businesses are taxed at top individual income tax rates plus, due to IRS minimums on how much of business income can considered non-wage, much of the payroll tax rate. Biden's plan to raise personal income and payroll rates would push their federal rates from below 40 percent to, often, above 50 percent, and these are on top of state income taxes. These are large tax increases facing business that employee tens of millions of workers. The exact calculations are more complicated than this, accounting for the complexities of tax depreciation schedules, investment tax credits and net

\footnotetext{
${ }^{2} 0.11=0.7 *(0.65-0.10) * 0.28$ plus rounding This illustration ignores the difference between economic depreciation and tax depreciation schedules under Biden's plan.

${ }^{3}$ See also the discussion in Willams (2020). Before the 2017 tax cut, the majority of workers were employed by a pass-through business (Pomerleau, An Overview of Pass-through Businesses in the United States 2015).
} 
interest deductibility, among other factors. These calculations are described below, and more detailed derivations are provided in Appendix I.

Regarding the calculator results for noncorporate business forms, we also find about a 12 percentage point increase from Biden's agenda, largely due to higher personal rates and the expiration of the qualified business income provisions of the 2017 tax law. These are the primary reasons why our more complicated calculator, described in what follows, shows an increase in the average marginal tax rate on business investment (corporate and noncorporate) of 12.5 percentage points.

\section{II.A. Measuring the intertemporal tax wedge}

When estimating effects of tax policies on investment, an important measure is the cost of capital, defined as the pretax rate of return on an investment required to break even after-tax. The cost of capital $\rho$ is defined by

$$
\rho=\frac{1-Z-F}{1-T}(r-\pi+\delta)-\delta
$$

In this equation, $Z$ is the present value of the tax shield from capital cost recovery (depreciation deductions, expensing and investment tax credits), $F$ is the present value of the tax shield from net interest deductibility, and $T$ is the average statutory tax rate faced by the firm over the life of the investment. $r$ is the nominal required return on assets, $\pi$ is the expected inflation rate, and $\delta$ is the economic depreciation rate of the asset. The tax terms $Z, F$ and $T$ are all forward-looking; the derivations of these terms and the issues relevant to modeling the cost of capital are presented in Appendix I.

The forward-looking nature of the equations used here is relevant to modeling the potential impacts of the Biden agenda. Under current law, the individual income tax provisions from the 2017 tax act are scheduled to expire in 2026 (except for chained CPI indexing), which was set to satisfy the Byrd rule limiting deficits beyond the budget window. Whether Congress would actually allow these tax cuts to expire is less clear, although the Biden campaign proposes to allow them to expire, in addition to more immediate changes to tax policy. Hassett and Metcalf (1999) and Viard (2017) have explored the potential investment disincentives introduced by 
time-varying and uncertain investment tax policies. By using forward-looking equations for the cost of capital, we can capture the incentive effects of anticipated future tax changes.

The cost of capital forms the basis of other important terms for measuring effects of tax policy on investment incentives. The sum of the cost of capital and the economic depreciation rate $\delta$ defines the user cost of capital, which serves as an input to the neoclassical growth model. A common measure of the wedge introduced by entity-level taxes (the corporate income tax for $\mathrm{C}$ corporations, and the taxation of pass-through business income) is the marginal effective tax rate (METR), defined as

$$
\operatorname{METR}=\frac{\rho-r+\pi}{\rho}
$$

In other words, METR is the wedge at the margin between the pre-tax return on capital and what the owners and creditors of businesses receive after business taxes. However, business income is subject to an additional layer of tax. Business income paid out as interest on a firm's debt is subject to taxation as interest income, corporate profits paid out as dividends are subject to taxes on dividend income, and corporate profits retained by the firm may be subject to capital gains taxes. Appendix I describes these tax distortions in greater detail and derives the weighted average after-tax return to savers $s$. Using this return to savers, we can define the marginal effective total tax rate (METTR) as

$$
\operatorname{METTR}=\frac{\rho-s}{\rho}
$$

Whereas the METR measures only the distortions from entity-level taxes, the METTR captures the entire distortion from capital taxation on the firm level and on investors. The METTR is the wedge between the pre-tax return on capital and what the owners and creditors of businesses receive after both business and personal taxes.

So far, following Hall and Jorgenson (1967), the measures presented focus only on the margin of increasing investment in a given firm in a given tax jurisdiction. However, in recent years additional attention has been paid to international investment decisions by large multinational enterprises (MNEs). When projects exhibit supernormal returns, the cost of capital and marginal tax rates are no longer sufficient to characterize investment incentives, as MNEs make extensive- 
margin investment decisions on which countries to locate the project. ${ }^{4}$ A useful measure of these new incentives developed by Devereux and Griffith (2003) is the effective average tax rate (EATR), which measures the tax rate faced by the entire project, instead of the tax rate only on the marginal rate of return. In general, the EATR is a weighted average of the METR and the statutory tax rate faced by the firm, with modifications to account for the international tax rules created by the 2017 tax act (i.e. FDII and GILTI). The EATR on a domestic project and on a foreign project are derived in Appendix I. Vice President Biden's plan affects the EATR less than the METR because the phase-out of bonus depreciation is less relevant to the domestic EATR and irrelevant to the foreign EATR.

To measure the potential effects of the proposed Biden tax agenda, we compute costs of capital and federal METRs by fixed asset type (92 asset types), by industry (62 industries) and by firm type (C corporation, S corporation, sole proprietorship and partnership). We allow the tax rates used to vary by firm type, with the rate for $\mathrm{C}$ corporations as specified by relevant law, and the tax rates for sole proprietorships, partnerships and S corporations computed using the opensource Tax-Calculator microsimulation model for the individual income and payroll taxes. ${ }^{5}$

To compute weighted averages, we use a breakdown of net stocks of fixed assets by asset type, by industry and by firm type. These are computed using the BEA detailed fixed asset tables, which provide net stocks and investment in fixed assets by asset type and industry. We combine this with BEA data on fixed assets by legal form of organization to split these between corporations, sole proprietorships and partnerships. We use the IRS SOI Tax Stats on returns of active corporations to split corporate assets into those of $\mathrm{S}$ corporations and those of $\mathrm{C}$ corporations.

The code to implement these computations is open-source. ${ }^{6}$ This is based on work by CBO (2014) and the open-source Cost-of-Capital-Calculator model. However, unlike these other

\footnotetext{
${ }^{4}$ Similar incentives are present for the decision to locate an investment in a business taking losses or one making taxable profits.

${ }^{5}$ Tax-Calculator can be accessed at https://github.com/PSLmodels/Tax-Calculator.

${ }^{6}$ The code for computing these measures of the distortions from capital taxation is available at https://github.com/codykallen/coc-fl.
} 
models, the equations used here are forward-looking, and we separately compute measures for different types of pass-through businesses.

Table 3 presents measures of federal capital tax distortions under a current policy baseline and under the Biden campaign's proposed tax changes. Note that a current policy baseline implicitly assumes that current tax policies are extended forward, including that the individual income tax provisions of the 2017 tax act are not allowed to expire and the extension of current bonus depreciation rates. These results are presented for three years: 2021, when the campaign's proposed tax changes could be enacted; 2025, the year before the expiration of many provisions of the 2017 tax act; and 2029, near the end of the budget window.

As can be seen in Table 3, under the current policy baseline, the federal METR on equipment and on intellectual property is negative. These negative METRs are a feature of the provisions of the 2017 tax act. Full bonus depreciation (for equipment and certain types of structures) and expensing (for research and development investment) eliminates the entire tax burden on the marginal investment. ${ }^{7}$ For equipment, the combination of full bonus depreciation and net interest deductibility causes the present value of the deductions from a marginal investment to exceed the present value of the pre-tax income from it, implying that a marginal investment in equipment receives a net subsidy. For intellectual property, these same effects hold, with the additional tax shield from the R\&D credit.

Unlike in the case of a positive tax rate, for investment receiving a net federal tax subsidy, an increase in the statutory tax rate increases the size of the subsidy. Accordingly, the Biden tax plan increases this subsidy (or makes the METRs more negative) on equipment and intellectual property for the initial years of the budget window.

The increases in the business tax rates come primarily from three proposed changes: raising the corporate tax rate to 28\%, phasing out the qualified business income (QBI) deduction, and extending the payroll tax to income above $\$ 400,000$. The phase-out of the QBI deduction raises

\footnotetext{
${ }^{7}$ For a marginal investment, the present value of the after-tax income stream generated by the investment is equal to initial cost of making the investment.
} 
marginal tax rates on pass-through business income, and the extension of the payroll tax raises marginal tax rates on sole proprietorship and partnership income through the self-employment tax. Although these provisions affect only a relatively small portion of pass-through business income, their effect on marginal tax rates is nontrivial, with the weighted average marginal tax rates on income from sole proprietorships, from partnerships and from $\mathrm{S}$ corporations rising by 1.1, 2.3 and 1.7 percentage points respectively in 2021. ${ }^{8}$ Initially, these tax hikes would apply only to a relatively small portion of entrepreneurs, which we define as tax filers reporting passthrough business income; in 2021, 4.9\% of entrepreneurs would face tax hikes, although this group earns $56.3 \%$ of total pass-through business income. However, after the expiration of the individual income tax provisions of the 2017 tax act, these tax hikes would apply broadly across entrepreneurs, with $72.4 \%$ of entrepreneurs (with $94.5 \%$ of pass-through business income) facing tax hikes by 2030 relative to the current policy baseline.

While pass-through tax hikes would affect nearly all pass-through income by 2030, the effect would vary across states, as some states rely relatively more on pass-through business activity than on other forms of economic activity. We examine these potential effects using the most recent County Business Patterns (CBP) data on employment in each state by type of employer. We can estimate the share of total employment affected by these pass-through tax hikes using the share of total employment from pass-through businesses in each state multiplied by the share of total pass-through income affected by the tax hikes. Figure 1 presents these estimates of the share of total employment in each state occurring in pass-through business facing tax hikes in 2020 under the Biden plan. These affected shares of total employment range from a low of 30.7 percent in Hawaii to 50.5 percent in Idaho. Idaho, Montana and Wyoming would be particularly heavily affected, as pass-through businesses provide a majority of employment in each of these states.

Although these higher tax rates increase the net subsidy to equipment and intellectual property in the initial years of the budget window, this effect reverses as bonus depreciation for short-lived

\footnotetext{
${ }^{8}$ The effect on tax rates on sole proprietorship income is smallest because it is less unequally distributed than partnership or S corporation income. The effect on partnerships is larger than on S corporations because $\mathrm{S}$ corporation income is not subject to the self-employment tax.
} 
assets phases out, resulting in large increases in METRs under the Biden plan across asset types, industries and firm types.

Although METRs are useful in showing effects of firm-level taxation, they omit the distortions from taxation of investment income. The Biden campaign has proposed subjecting long-term capital gains and qualified dividends-which are traditionally subject to a preferential tax schedule to mitigate issues of double taxation of corporate economic activity-in excess of \$1 million to the top statutory rate of $39.6 \%$, as well as eliminating step-us basis to tax capital gains at death. Returning the top statutory rate from 37 to 39.6 percent raises the marginal tax rates on short-term gains, nonqualified dividends, and interest, although these effects are smaller. The METTRs in Table 3 demonstrate how these higher investor-level taxes more than offset the greater tax subsidy on equipment and intellectual property from firm-level taxation. The Biden plan would raise the METTRs on all asset types in 2021, with larger increases in later years. The effect on intellectual property investment is particularly drastic. Whereas R\&D investment is the only asset class to receive a net subsidy in the tax system (negative METTR) under current policy, this would reverse under the Biden plan, with intellectual property facing a positive net tax wedge in later years of the budget window, in spite of full expensing, interest deductibility and the R\&D credit at the firm level.

For purposes of analyzing the national effects of capital taxation on economic aggregates, measures of the tax wedge on saving and investment need to include the effects of state and local taxes. We adjust the tax rates used in our cost of capital calculations to include state and local taxes on corporate income and on pass-through business income. We also include the distortion from state and local taxes on investment income when calculating the return to savers, and we include property taxes on tangible assets. Appendix I describes this in greater detail.

Table 3 presents the combined METRs and METTRs from federal, state and local taxes, to compare against the measured tax wedges when only considering federal taxes. For 2029, including state and local taxes raises the METR under the baseline from -4.6 percent to 10.2 
percent, a difference of 14.8 percentage points, primarily due to property taxes. ${ }^{9}$ Including state and local taxes raises the baseline METTR by 14.8 percentage points. Including state and local taxes raises the METR under the Biden proposals by 12.3 percentage points and raises the METTR by 11.9 percentage points. The effect of state and local taxes is smaller than under the baseline because of the expiration of the $\$ 10,000$ cap and deductions for state and local taxes paid. $^{10}$

In addition to these intensive-margin investment effects, the Biden campaign's proposed tax policies would raise effective average tax rates on both domestic and foreign investment with supernormal returns. Under current law, such investments made in the United States may be eligible for the Foreign-Derived Intangible Income (FDII) exclusion, which offers a 37.5\% deduction for foreign-derived income in excess of $10 \%$ of tangible assets. ${ }^{11}$ To increase the international competitiveness of the U.S. tax system, this provision created an incentive for firms with supernormal profits (especially those derived from intangible assets without a physical location) to locate their investments in the United States. This provision was paired with a surtax on supernormal profits of U.S. firms with low foreign tax rates via the minimum tax on Global Intangible Low-Taxed Income (GILTI), which automatically includes income earned in foreign affiliates of U.S. MNEs in excess of $10 \%$ of tangible assets in taxable income, with a $50 \%$ exclusion. Under current law, this results in a marginal tax rate of $10.5 \%$ on these supernormal profits. The Biden campaign has proposed raising this GILTI tax rate to $21 \%$.

Table 3 also presents the average EATR on a domestic investment that sells to foreign buyers and on a foreign investment selling product to foreign buyers. Because GILTI is applied on a company's global income (which effectively allows firms to use taxes paid in high-tax countries to offset taxes avoided in low-tax countries), we use the average foreign tax rate faced by U.S. MNEs by industry, calculated from BEA data on activities of these MNEs. Under both the current policy baseline and the Biden proposal, the EATR on foreign investment exceeds that on

\footnotetext{
${ }^{9}$ For context, suppose both the cost of capital and the required real return on assets are 5\%, which gives a METR of zero. If a $1.25 \%$ property tax (with a $21 \%$ offset from deductibility of business property taxes) is included, this raises the cost of capital to $5.99 \%$, which gives a METR of $16.5 \%$.

${ }^{10}$ The SALT cap applies to individual income only. Deductions for property taxes on business property are not affected.

${ }^{11}$ This generally only applies to income derived from (and assets related to) foreign use of the firm's products. Under current law, the deduction rate decreases to $21.875 \%$ in 2026.
} 
domestic investment. However, under the Biden plan, these would essentially equalize by 2029, eliminating the small tax advantage to domestic investment created by the 2017 tax act.

Finally, we can consider effects on measured TFP of inefficiencies in the allocation of investment across asset classes, industries and firm types arising from non-uniform capital taxation. Table 3 also presents the cross-sectional standard deviation of the cost of capital. The Biden campaign's proposals would increase this variation, exacerbating the misallocation of investment and potentially reducing aggregate total factor productivity. To be conservative, we treat this TFP effect as zero.

These results feed into our macroeconomic analysis of the overall agenda by providing the tax and productivity parameters in Table 2 . The 12.5 percent addition to the rate of capital incometaxation shown in the second row corresponds to the change in the METTR in 2029 inclusive of state and local taxes shown in Table 3. We take as the baseline extending all of the 2017 tax provisions. The small entries in the second row of Table 2 for labor taxation and TFP come from the change in the payroll tax rate for earners above $\$ 400,000$ annually. Because they are a small share of employment and a larger share of labor income, taxing their supply affects the "quality" of labor as the concept is used by Jorgenson (2009) and others in the productivity literature.

\section{II.B. Capital-income taxes and market equilibrium}

Market equilibrium equates the benefit of investment to its tax-inclusive cost $\rho$. In a long-run steady state, the benefit is the net-of-depreciation marginal product of capital. Therefore, in the long run METTR is the wedge between the after-tax return to savings and the net marginal product of capital.

Any empirically-grounded estimate of the effects of taxes (or business regulation) must confront the fact that national average after-tax returns on capital have been fairly constant over long periods of time and across a broad cross section of countries despite large differences in rates of capital taxation. ${ }^{12}$ This is strong evidence that, in the long run, the owners of capital have close

\footnotetext{
${ }^{12}$ For example, calculations of after-tax capital-rental rates for the twentieth-century U.S. find rates of about 8 percent per year at the beginning of the century - when corporate and personal income taxes were unconstitutional -
} 
substitutes to investment in the businesses of a specific country. Faced with a high tax rate on their capital income, eventually they reduce investment in the jurisdiction until pre-tax profits are high enough to compensate for the high tax rate. In effect, workers and consumers eventually pay for capital-income taxes rather than the capital owners who are legally liable for the tax.

We therefore assume that the long-run after-tax return to savers is independent of the METTR. In the language of the neoclassical growth model, that is a constant rate of time preference $\kappa$, which pins down long-run equilibrium capital intensity.

$$
\operatorname{MPK}\left(\frac{K}{L}, A\right)-\delta=\frac{\kappa}{1-\operatorname{METTR}}
$$

where $K / L$ denotes capital intensity and $A$ denotes total factor productivity. With constant returns in aggregate production, the marginal product of labor is also pinned down by capital intensity. In other words, this condition by itself, without regard to the rest of the growth model, tells us the magnitude of the effect of capital taxation on the long-run marginal product of labor: ${ }^{13}$

$$
d \ln M P L=-\frac{1-\alpha}{\alpha} d \ln (\rho+\delta)=\frac{1-\alpha}{\alpha} \frac{\rho}{\rho+\delta} d \ln (1-M E T T R)
$$

where "labor's share" $\alpha$ denotes the share of $L M P L$ in gross output and $\rho+\delta$ the user cost of capital. In words, capital taxation reduces the long run marginal product of labor with a magnitude that depends only on the magnitude of two shares: labor's share and the share of the cost of capital $\rho$ in the user cost of capital $\rho+\delta$. With, for example, a labor's share of 0.7 and a user-cost share of $1 / 3$, each seven percent that policy reduces the after-tax share reduces long-run $M P L$ by one percent. Because we find that Vice President Biden's agenda reduces the average

and also about 8 percent at the end of the century (C. B. Mulligan 2002). For cross-country patterns, see Caselli and Feyer (2007).

${ }^{13}$ Moreover, the log of average product of labor changes in proportion to the change in the log of the marginal product of labor, with proportionality factor equal to the elasticity of substitution in production between capital and labor. See Jaffe et al (2019, Chapter 18) for proofs. These quantitative results do not require labor's share to be a constant, as it would be with Cobb-Douglas aggregate production. Quantitative results for other variables, such as capital intensity or GDP require additional information such as the magnitudes of the elasticity of substitution in production or wage elasticities of labor supply. 
after-tax share of capital income by sixteen percent, it should be no surprise that we find the capital-tax part of his agenda to reduce the long-run MPL by more than two percent. See also our sensitivity analysis in Appendix II.

This type of capital-tax analysis is sometimes accused of missing the mark by excluding "monopoly" and loopholes in business tax laws (Summers 2017). Jaffe et al (2019, Chapter 18) show how these accusations are wrong, or at best misleading. Constant-rate markups in factor and goods markets can be introduced without changing even the quantitative results. Other forms of imperfect competition enlarge the burden that capital-income taxation has on labor. Loopholes may reduce the aggregate burden of capital-income taxation, although instead they may change the composition of the burden from reduced capital accumulation to reduced TFP. ${ }^{14}$ Table 3's results on the heterogeneity of tax rates shed some light on this.

Another criticism is that our model does not have any role for business activity to affect TFP growth. We agree that TFP growth is not automatic, and much of it originates with activities related to innovation and entrepreneurship. Lacking a quantitative understanding of this process, we treat them as zero in this paper but do not deny the assertion that additional taxes and regulations would reduce the growth of TFP and not just its level.

\footnotetext{
${ }^{14}$ Our calibration of the neoclassical growth model with broad-based taxes has both factor-income taxes on the upward side of their Laffer curves and the combined Laffer curve. With enough loopholes, real-world taxes would contradict this assumption.
} 


\section{Climate and Energy Policy}

While the Trump Administration has built its energy policy around increasing production of fossil fuels, Vice President Biden focuses his energy proposals around climate. Policy proposals in this area are muddled by the high profile of the Green New Deal, which has support among many Democrats. Vice President Biden’s proposals do not line up perfectly with the Green New Deal, though they share a focus on climate. Federal climate policy has been slow to develop in the United States versus other OECD countries, though several states have adopted climate policies that contribute to actions that help reduce emissions relative to a baseline. Despite the lack of federal coordination, the United States appears poised to meet 2020 emissions targets, mostly because of increased reliance on natural gas, which is far less carbon intensive than coal (Council of Economic Advisers February 2020, New Climate Institute 2020).

Vice President Biden proposes more than a dozen climate and energy policies aimed at reducing America's carbon footprint, each of which has opportunity costs in terms of less economic activity in the short run and benefits in terms of reduced global warming. These policies are detailed in Table 4. Some of these policy proposals are unlikely to impose large short-term costs, such as halting the U.S. withdrawal from the Paris Agreement or reverting to Obama-era rules to limit fugitive methane emissions from oil and gas operations. ${ }^{15}$ Others, such as those discussed below, would likely impose substantial economic costs. We quantify the opportunity costs of four climate policies that are likely the most impactful among Biden's proposals. The first would reduce fossil fuel consumption by light- and medium-duty vehicles by raising average fuel economy regulations, in an effort to erode the reliance of the transportation sector on petroleum. The second would increase the share of electricity generation from renewable sources in an effort to reduce emissions. The third would require additional renewable electricity generation to help satisfy the electrification of transport. A fourth, holding companies financially liable for historically emitted carbon and other pollutants, may help finance subsidies for renewables, but

\footnotetext{
${ }^{15}$ Moreover, the costs of methane-emissions limits are already counted separately in the CEA sample of 20 regulations. Further consideration could be given to the relative costs of fuels- and climate-focused approaches to energy and environment, in particular the distributional and geopgraphical impacts as in Brown, Fitzgerald, and Weber (2019).
} 
would impose additional opportunity costs, such as the impact of the implied higher uncertainty regarding future after tax profits.

These plans are ambitious. Unless people drive a lot less, the electrification of all, or even most, passenger vehicles would increase the per capita demand for electric power by about 25 percent at the same time that more than 70 percent of the baseline supply (i.e., electricity generated from fossil fuels) would be taken off line and another 11 percent (nuclear) would not expand. To put just the 25 percent in perspective: that is the amount of the cumulative increase in electricity generation per person since 1979, which is a period when nuclear and natural gas generation tripled. Taking the scale of the transformation into account, even before seeing the details, it should be no surprise that such ambitious policies will be expensive, to the point of dominating the economic costs of Vice President Biden's overall agenda.

In our effort to enumerate the opportunity costs of the policy proposals, we do not assess the benefits those policies might deliver aside from rough estimates of the tonnage of carbon abatement. Climate change is real. It threatens to impose sizeable costs on people around the world, including in the United States. Changing the current trajectory would in some scenarios provide substantial economic benefits to future citizens. Given the global public good nature of emissions reductions, it is clear that U.S. citizens would capture some share of global benefits from these policies, but would bear all of the costs. ${ }^{16}$ By similar logic, the global benefits of these solitary actions by the U.S. would be minimal. One way to interpret our focus on costs is to identify cost-effective policies for climate policy. Accounting for direct and opportunity costs is a first step. A full accounting of the benefits would determine if the costs are worth incurring, including distributional implications of both benefits and costs.

\section{III.A. Regulation of Motor Vehicle Fuel Efficiency}

For better or for worse, the United States has focused policy efforts on average fuel economy standards, even though more efficient alternatives exist (West and Williams 2005). These policies lead to a number of dynamic responses by both producers and consumers of motor

\footnotetext{
${ }^{16}$ This issue leads to the divergence between global and domestic social cost of carbon, which has been acknowledged at least since 2010 (United States Government, Interagency Working Group on Social Cost of Greenhouse Gases 2010).
} 
vehicles, which can complicate analysis of the benefits and costs (Bento, et al. 2020). Candidate Biden (2020) pledges "rigorous new fuel economy standards aimed at ensuring $100 \%$ of new sales for light- and medium-duty vehicles will be zero emissions." This approach shares a common objective with other current policy proposals in this area, such as California governor Gavin Newsom's ban on non-electric vehicle sales after 2035. The baseline for our analysis is the current law, representing a rollback of increased average fuel economy regulations that were imposed during the Obama Administration. We estimate a lower bound on the cost of this pledge by estimating the private-sector cost of increasing average fuel economy standards from 45 miles per gallon (MPG) to 80 MPG.

We take the private-sector cost function to be quadratic in MPG, and therefore its marginal cost of increasing MPG to be linear in MPG. ${ }^{17}$ We estimate the marginal cost schedule with information about two of its points, as illustrated in Figure 2. The first point is the \$18 marginal cost estimated by Anderson and Sallee (2011) at 25 MPG (model year 2006). The second point is the average marginal cost of \$116 inferred from inter-manufacturer trades in carbon credits during the model years 2012-2016. Because the carbon credits were bankable, we treat the model years 2012-2021 as a single "fleet" with expected average standard fuel economy of 36 MPG. Moving along this cost function to the 80 MPG point would cost more than $\$ 12,000$ extra per vehicle, which is the shaded area in Figure $2 .{ }^{18}$ Fewer vehicles would be sold in this situation. Applying the $\$ 12,000$ to actual sales as well as a lesser cost to foregone sales, we estimate the annual private cost of Vice President Biden’s pledge to be at least $\$ 186$ billion, not including the costs of expanding the electricity-generation industry's capacity. Even if increasing fuel efficiency from 45 MPG to 80 MPG cut in half emissions by new passenger vehicles, and did not unintentionally increase emissions elsewhere in the economy, the average cost per ton of

\footnotetext{
${ }^{17}$ We note that the actual cost function is likely more convex than quadratic in the relevant range because compliance with an 80 MPG standard requires consumers to forego essentially all vehicles with fuel economy less than a Toyota Prius, which itself would be less than the fleet average. So this assumption is a conservative one.

${ }^{18}$ At 80 MPG, the marginal cost is about $\$ 512$ per MPG per vehicle. At the baseline MPG of 45 , the marginal cost is about \$197. Therefore the average marginal cost of the first increase in MPG and of the last increase in MPG is about \$355 per MPG per vehicle. Applied to a 35-MPG increase in the standard, that is more than $\$ 12,000$ per vehicle. Our approach does not specify to what degree this cost is borne as higher retail prices versus lesser vehicle quality as perceived by consumers. Bento et al (2020) point out that producers may sell some high-efficiency vehicles below marginal cost as a strategy to comply with fuel efficiency standards. That behavior reduces costs borne by consumers but compounds the costs to producers. This paper does not fully describe the incidence of those costs.
} 
carbon abated would be an order of magnitude above the global environmental benefit. Put another way, continuing to ratchet up fuel economy standards delivers expensive emissions abatement.

Such a policy would have other, indirect effects as well. First, consumers would be likely to change the portfolio of older cars in subtle ways. Older vehicles that are less fuel-efficient would likely stay in the fleet longer, because replacements would be harder to obtain. At the same time, more fuel-efficient used cars would be more likely to be scrapped because still more efficient new vehicles would be able to be purchased under the policy. These two effects combine to reduce the marginal effect of continuing to use an average fuel economy standard instead of a different instrument (Bento, et al. 2020). It could be that a higher standard would help spur a technological breakthrough in manufacturing fuel-efficient automobiles. We are skeptical that regulation is the most cost-effective way to promote technological innovation.

\section{III.B. Renewable Electricity Generation}

Vice President Biden proposes to fundamentally transform the U.S. electricity generation system by requiring a “carbon pollution-free power sector by 2035."19 Because wringing the last bit of emissions from the power sector could be prohibitively expensive, we do not take this pledge literally. Instead we quantify the effects of a somewhat less ambitious policy of 80 percent of generation to come from emission-free sources by 2050, which has been modeled by Department of Energy personnel (Mai, et al. 2014). It is notable that the Biden plan promises to do this without affecting consumer price, effectively allowing end users to enjoy the same amount of electricity while reconfiguring the generation architecture of the U.S. electric grid.

In 2019, about 18 percent of electricity was generated by renewable sources (including hydroelectric but not nuclear). The platform is silent on the expansion of either hydroelectric or nuclear generation, so we hold those sources constant and model the policy as substituting renewable for fossil generation. In 2019, nuclear generated 20 percent of the annual total, although the nuclear share will likely fall as older plants are retired. Following Mai et al (2014),

\footnotetext{
${ }^{19}$ https://joebiden.com/clean-energy/
} 
we interpret the platform as increasing (non-nuclear) renewable generation from 18 to 68 percent of total generation. We focus on the aggregate quantity of electricity provided, rather than a more granular analysis taking constraints on delivery into account. This is consistent with our understanding of the platform. To the extent that physical constraints bind more than Mai et al (2014) model them, our estimate of the costs is conservative. ${ }^{20}$

We calculate the cost of increasing the renewable share of electricity generation from 18 percent now to 80 percent by 2050. In keeping with the Democratic platform documents that highlight the importance of not raising retail prices for groups of consumers, we assume the goal is achieved by subsidizing renewables and taxing nonrenewables in order to achieve the share target without affecting the net-of-subsidy retail price of electricity and thereby the quantity of electricity consumption. Because we allow for a portion of net generation to be fossil-based, we are implicitly assuming that remaining fossil generation can handle reliability and consistency constraints, which could be an issue for certain times and places in a more renewable-dependent electric grid.

Figure 3 illustrates our cost calculations, showing generation quantities on the horizontal axis and marginal costs on the vertical axis. The green curve is the marginal cost curve for renewables while the black curve is the curve for fossil fuels. Because we show the fossil-fuel curve as a mirror, moving to the right in the figure indicates a change in the composition of generation without changing the total. Holding the total generation constant, for the moment, makes sense if consumer demand does not shift and the policies are implemented in such a way as to hold retail prices constant. The baseline quantity's marginal costs are indicated with the gray vertical line. The blue vertical line shows the result of achieving the 80 percent target.

The quantity of electricity changed from nonrenewable to renewable (2.1 billion megawatt-hours (MWh) per year) requires a resource cost equal to the cost difference between the two sources of

\footnotetext{
${ }^{20}$ Mai, Bistline, et al. (2018) studied the predictions of different energy system models to determine modeled paths for renewable penetration into electricity generation. None of the models approached the 80 percent target. How much of the target is realized due to market rather than policy incentives determines the opportunity cost of action. Renewable electricity generation has some attractive economic attributes, such a very low or zero marginal cost. While this pulls more renewables into the generation mix, the relatively high fixed costs create an offsetting incentive that policy often targets. Where this comes out is unclear (Heal 2020), and is the reason we rely on energy forecasts.
} 
supply. In the baseline, there is already a resource cost difference at the margin due to longstanding subsidies for renewables. We estimate that difference to be $\$ 22$ per MWh, which is the baseline vertical distance shown in Figure 3 between the two marginal cost curves. According to Mai et al (2014), expanding renewables to 80 percent would add another $\$ 50$ per MWh to the marginal cost of renewable supply. Meanwhile, the gap between marginal supply sources increases another $\$ 16$ by moving down the supply curve for nonrenewables. ${ }^{21}$ On average, that is a cost gap of \$55 per MWh, bringing the total industry resource cost to \$115 billion annually, as entered in the bottom panel of Table $5 .^{22}$ In other words, $\$ 115$ billion is the additional cost for the industry to produce the same quantity of electricity. Previous work has demonstrated that the marginal cost increase is linear up to the 80 percent threshold (Elliston, Riesz and MacGill 2016).

The high renewable generation outcome can theoretically be achieved with renewable subsidies of $\$ 202$ billion annually and nonrenewable taxes of \$13 billion, which is a net subsidy of \$189 billion annually. ${ }^{23}$ We assume that is financed with relatively efficient taxes, namely flat-rate labor-income taxes and excise taxes on consumption goods. These excise taxes may include settlements with oil and other companies pursuant to the fourth item of Vice President Biden's agenda that we assess: to punish companies that emitted carbon and other pollution in the past. As noted previously, $\$ 115$ billion of this is an annual resource cost, which makes the remaining $\$ 58$ billion a redistribution to the inframarginal suppliers of renewables. This redistribution itself has a deadweight cost in the labor market, which for the purposes of Tables 5 and 6 we assume to be $\$ 0.50$ per dollar or $\$ 29$ billion annually. ${ }^{24}$ Combining the industry resource cost and the

\footnotetext{
${ }^{21}$ We obtain the $\$ 16$ by assuming a price elasticity of nonrenewable supply of two. This is the price elasticity of supply across all fossil sources, which exceeds the supply elasticity across single fuels, which themselves show evidence of raising in recent years (Newell and Prest 2019, Newell, Prest and Vissing 2019).

${ }^{22}$ Expanding renewables the first MWh costs only \$22 more than the nonrenewable alternative whereas the last MWh of renewables costs $\$ 22+50+16$. To a first-order approximation, the quantity-weighted average of the extra costs in between is the average of these two endpoints; this is a generalization of the Harberger-triangle method.

${ }^{23}$ To be conservative as to the impact of Vice President Biden's agenda, we assume that the federal government obtains the $\$ 13$ billion in annual fossil-fuel taxation without losing any of its existing revenue from mineral royalties and leases. More likely the losses would be in the single-digit billions.

${ }^{24}$ Labor tax collections that are consumed as part of the policy have income and substitution effects on aggregate labor supply, which we assume exactly offset. The collections that are redistributed have, to a first approximation, only the substitution effect, which is reflected in the 50 percent marginal deadweight cost factor. Note that in using the neoclassical growth model we do not separately assume labor-market deadweight costs because those are outcomes of the model.
} 
labor market deadweight costs, Vice President Biden’s electricity generation costs $\$ 144$ billion annually.

Because the additional "resources" used in electricity generation are ultimately some combination of labor, capital, and raw materials, our approach is qualitatively consistent with Vice President Biden's claim that his plan would create jobs in that industry. ${ }^{25}$ However, in order to reach conclusions about aggregate employment, we must keep track of all of the parties to a subsidy transaction, including taxpayers and lenders to the government, which we do with the neoclassical growth model. We must also recognize that Vice President Biden's plan affects the real wage either by taxing labor or consumption to pay for the subsidies, as in our model, or by increasing the real price of energy.

At first glance, subsidizing renewable energy would be analogous to hiring workers to build roads or military bases, which are projects shown to increase aggregate employment (Ramey 2011). To the extent that the analogy is apt, we note that employment increases less in the aggregate than in the industry; the projects reduce employment outside the industry. However, road and military projects are often temporary and thereby not financed by a commensurate and contemporaneous tax on labor or consumption, whereas the additional resources used by renewable energy will be ongoing. Moreover, perhaps unlike road building and other projects, the added annual tax burden for expanding renewable energy, $\$ 173$ billion, significantly exceeds the annual cost of the resources drawn into the industry, $\$ 115$ billion.

\section{III.C. Incidence by State}

In addition to consumers and producers, transitioning away from reliance on fossil fuels affects one other important group of Americans. The United States is unique in the world insofar as private citizens own the majority of the mineral deposits. In other countries, devaluing fossil fuel deposits undermines only the government's balance sheet. While U.S. federal and state

\footnotetext{
${ }^{25}$ In order to calculate an increase in energy-industry employment, one could assume that the new activity in the industry is about as labor-intensive as the rest of the economy with about the same annual compensation per employee. If so, that would be about 1.3 million additional energy-industry jobs in the long-run, including the employees needed to expand capacity to accommodate additional electric vehicles (Section III.C). As explained below, this additional employment comes at the expense of even more jobs outside the energy industry.
} 
governments own substantial mineral property, about three-quarters of production comes from private mineral property.

Table 7 shows the value of proved reserves of oil, natural gas, and coal at the end of 2018. We estimate these values from state-level proved reserves published by EIA, applying a version of the net price rule suggested by Davis and Cairns (1999). ${ }^{26}$ The value of the deposits in the ground is $\$ 4.95$ trillion. The table shows the composition of this value across different fuels and different states, taking into account both physical and geographical differences in reserves. The energy embodied in a barrel of oil is more valuable than the same amount of energy in a coal deposit, just as reserves on the North Slope of Alaska are likely to be less valuable than comparable reserves located nearer to population centers.

Oil reserves account for just over half of the total value, even though domestic petroleum accounts for only about one-third of energy attributable to domestic fossil fuel production. In contrast, coal accounts for only about 11 percent of the total proved reserves value, even as it contributes twice as much to the proportion of domestic fossil fuel production. The single largest category is the value of proved oil reserves in Texas-we estimate those reserves to be worth over $\$ 1.1$ trillion, or about 40 percent of the total U.S. proved oil reserves.

The table gives a sense of incidence of an anti-fossil fuel policy. The states with the largest values of natural capital stocks in fossil fuels are Texas, North Dakota, Pennsylvania, Oklahoma, New Mexico, West Virginia, and Wyoming. Policies that restrict the production of fossil fuels will especially pass through to the value of the natural capital assets. Private citizens own over 70 percent of these assets and stand to absorb lower capital values. Because of absentee ownership, citizens in states other than where resources are located may absorb lowered values; Texans control mineral rights across the country (Brown, Fitzgerald and Weber 2019).

The variation in ownership of mineral reserves varies across states. The federal government is a major mineral owner, especially in western states. The federal government also controls most

\footnotetext{
${ }^{26}$ Using proved rather than technically-recoverable reserves makes this figure conservative relative to the total amount of fossil fuel resources in place in the United States. This measure makes for a more relevant estimate of the resource that has been demonstrated to exist and is profitable to extract at current prices.
} 
offshore resources. We make estimates of the disposition of fossil fuel reserves. ${ }^{27}$ We estimate that the federal government owned proved reserves worth at least $\$ 785$ billion. This compares to an estimate of $\$ 309$ billion (1981\$) by Boskin et al. (1985), which would be $\$ 722$ billion in $2018 .{ }^{28}$ In 2019 the federal government earned a return of $\$ 8.6$ billion from fossil fuels in 2019, amounting to a total of 93.5 percent of federal natural resource revenue.

As we have modeled Vice President Biden’s agenda, nonzero fossil fuel production would still occur in the U.S. and inframarginal fossil fuel reserves would still retain some value. According to our Figure 3, fossil fuel producers lose in two ways: producing less and paying tax on what they do produce. The total of these is $\$ 30$ billion annually, as shown in Table 5. Discounted at the after-tax return used throughout this paper, that loss has a present value of $\$ 841$ billion, or about $\$ 6800$ per household on average. ${ }^{29}$

\section{III.D. Renewable Electricity Generation for an Electric Vehicle Fleet}

In addition to improving average fuel efficiency of petroleum-fueled vehicles, increasing penetration of electric vehicles into the fleet can help mitigate carbon emissions. Electric vehicles rely on the electric grid for charging, and the underlying grid is much greener in some parts of the country relative to others, such that an additional electric vehicle has negative climate benefits in some states (Holland, Mansur, et al. 2016). Furthermore, the costs of those emissions is not limited to global stock pollutants, and some populations bear disproportionate costs from electric generation for additional vehicles (Holland, Mansur, et al. 2019). In part in response to these studies, the Biden plan proposes to serve incremental demand for electricity to charge vehicles with renewable generation.

If households are to maintain their uses of electricity as well as charge their electric vehicles, more electricity generation would be needed than assumed by Mai et al (2014). We calculate

\footnotetext{
27 These estimates use ownership shares from Fitzgerald and Rucker (2016).

${ }^{28}$ Boskin et al (1985) attempt to place a value on both undiscovered and discovered resources. Proved reserves are a subset of discovered resources.

${ }^{29}$ Arguably, producers might be able to mitigate these losses by accelerating their production before the fossil-fuel restrictions take full effect. Accelerated fossil production would hurt the short run economics of renewable energy, and possibly contribute adversely to climate change more than the baseline policy does. Also note that Table 7 estimates the cross-state incidence by the location of production; the owners of the production factors could live elsewhere in the country or even outside the U.S.
} 
that this incremental demand is 1 billion MWh per year and would increase the marginal cost of renewables from $\$ 117$ per MWh to $\$ 136$ (Table 5). The expanded-capacity allocation is shown in Figure 3 as the two vertical red lines indicating movements up both the renewable energy and the fossil fuel supply curves. The additional resource and social costs are shown in Table 5 as $\$ 62$ billion per year and $\$ 71$ billion per year, respectively. The cost of generating the extra 1 billion MWh using the baseline fossil fuels at baseline marginal cost ( $\$ 45$ per MWh) is counted separately in our estimate of the cost of increasing vehicle fuel efficiency. ${ }^{30}$

\footnotetext{
${ }^{30}$ Specifically, in using the GHG credit market as the foundation for Figure 2, we already recognize consumers'
} willingness to incur higher electric bills in order to economize on fueling their vehicle. 


\section{Business and Labor Regulation}

By all accounts, federal regulation has been atypical during the Trump administration, both by executive agencies and independent agencies. Executive Order 13771, issued on January 30, 2017, put each executive agency on a regulatory budget. As a result of, or at least coincident with, the EO, new significant regulations almost stopped entirely and hundreds were removed (CEA 2020). Independent agencies have removed regulations ranging from business-to-business price controls in the internet industry to determinations that students are employees of their universities.

In principle, pursuant to executive orders by Ronald Reagan and subsequent presidents, the costs and benefits of each regulation would have been rigorously quantified and characterized by the issuing agencies so that simple addition would provide estimates of changes over time in regulatory costs and benefits. As documented by McLaughlin and Mulligan (2020) and the literature cited therein, the reality is that cost estimates are usually (more than 99 percent of the time) absent from published rules. When cost estimates are present, they are (contrary to OMB guidance) often absurd. ${ }^{31}$ Most important for the purposes of this paper, estimates of opportunity costs are almost always absent from federal rules. ${ }^{32}$

In an attempt to more rigorously quantify the totality of costs and benefits of newly issued regulations (and deregulations) during the past two administrations, the Council of Economic Advisers followed a two-step approach. First, because regulations are undoubtedly heterogeneous in their costs and benefits, it identified the top 20 in terms of attention from the public. $^{33}$ Second, CEA closely examined each of the 20 and for each conducted a cost-benefit analysis that included estimates of opportunity cost.

\footnotetext{
${ }^{31}$ Cost estimates in rules issued by the Environmental Protection Agency and the Department of Transportation are often serious. McLaughlin and Mulligan (2020) show that the regulations issued by these agencies are a small minority of the stocks and flows all federal regulations.

${ }^{32}$ Because economically important regulations - such as those prohibiting multi-billion dollar market segments - are often designated as "economically insignificant" or "guidance documents" by the issuing agency (exempting them from quantifying costs and benefits), we doubt that the cross-regulation correlation between true costs and agency estimates is even positive.

${ }^{33}$ Attention by the public is measured through attention from Congress or comments submitted directly to the issuing agency. Most regulations get zero attention from the public by these metrics.
} 
One pattern that emerges from an examination of the top-commented regulations is that environmental regulations receive comments that are disproportionate to their costs. The Waste Prevention rule was the top commented rule of fiscal year 2018, receiving almost a million comments. The regulation that it removed was costing only about $\$ 100$ million annually because it applied only to federal and tribal lands. By comparison, rules interpreting ERISA to prohibit various Association Health Plans (AHPs) were costing almost $\$ 10$ billion annually whereas the FY 2018 action relaxing this interpretation received less than one thousand comments.

The findings of McLaughlin and Mulligan (2020) reinforce this pattern. In other words, judging by public attention federal regulation would seem to be primarily addressed to environmental issues whereas in fact for every environmental regulation there are many nonenvironmental rules, especially rules restricting business practices. If this pattern continued in a Vice President Biden administration, then the regulation of business practices (such as using the regulatory authority of the Federal Reserve to promote racial equality) may prove to be disproportionate to the attention such regulations are given in the campaign platform (Epstein 2020).

The distinction between environmental regulations and nonenvironmental regulations is also relevant for modeling the macroeconomic effects. Often environmental regulations primarily reduce private productivity by requiring businesses to produce environmental goods (or cut back on environmental bads) as part of producing their private goods, whereas nonenvironmental regulation often involves a significant transfer from consumers to producers. In terms of our Table 2, environmental regulations reduce TFP whereas an important part of nonenvironmental regulation is akin to an excise tax, except that the "revenue rectangle" does not go to the public treasury. These two effects are not easily distinguished solely on the basis of the effect of regulation on retail prices in the regulated industry. ${ }^{34}$

Based on the sum total of the 20 regulations and deregulations sampled, CEA estimated that deregulation between 2017 and 2019 reduced annual regulatory costs by $\$ 220$ billion relative to a regulatory freeze. They found that, after five years, a regulatory freeze would reduce annual

\footnotetext{
${ }^{34}$ One of CEA’s findings is sharp reductions in retail prices immediately after a deregulation took effect.
} 
regulatory costs by $\$ 133$ billion relative to the 2001-16 trend. The sum of these is the impact of 2017-19 deregulation relative to the previous trend. However, 21 percent of CEA's costs are the factor-market deadweight costs of the redistribution (from consumers to producers) created by a regulation, which is an effect that we consider in our growth model framework and therefore cannot include that part of CEA's estimate in Table 2 without double counting. We therefore take the costs to be $\$ 279$ billion, which is a mix of redistribution (akin to an excise tax) and productivity loss. To be conservative, our benchmark specification takes the entire amount to be redistribution and as a sensitivity analysis we take the other extreme. Table 2 shows the redistribution from consumers to producers implemented as the equivalent of 1.9 percentage points added to the labor wedge, which is approximately the rate needed to have a $\$ 279$ billion annual revenue rectangle. Note that our excise-tax approach implicitly treats the $\$ 279$ billion simultaneously as a cost to taxpayers and a benefit to others (producers) receiving the revenue represented by the rectangle; it only matters in the aggregate because the addition to the labor wedge comes on top of a nontrivial baseline labor wedge.

In terms of regulatory costs, the leading deregulations in CEA's 20 were removing the individual mandate to purchase health insurance, internet deregulations such as removing "net neutrality" business-to-business price controls and prohibitions against internet plans that did not meet federal privacy standards, removing prohibitions of short term health insurance plans and the aforementioned AHPs, the removal of state-level employer mandates to provide retirement plans, and removing regulatory barriers to manufacture generic drugs. The only environmental rules among the 20 are the Stream Protection rule and the aforementioned Waste Prevention rule. A full list of CEA's 20 regulations and deregulations is provided in the 2020 Economic Report of the President. 


\section{Labor wedges from new ACA policies}

Vice President Biden proposes four major changes to the individual insurance markets created by the Affordable Care Act (ACA). First, premium tax credits would become more generous. Second, premium tax credit eligibility would be expanded by eliminating the income ceiling. Third, the Federal government would offer plans alongside private exchange plans. Fourth, persons age 60-64 (many of whom were ACA customers) could buy into Medicare. All of these potentially affect marginal tax rates on employment and labor income.

From an aggregate perspective, the combination of these ACA modifications resembles an increase in person-weighted average marginal labor income tax rates of 2.4 percentage points, or 1.7 percentage points income-weighted.

While providing the detailed calculations below, we note that the order of magnitude of these results should be no surprise. Mulligan (2015, Figure 1.1 and Table 2.3) estimated that (i) the creation of the ACA increased the average marginal tax rate on labor income by about six percentage points, and (ii) the creation of Western European universal coverage programs increased the average marginal rate by about seven percentage points. Here we estimate that Vice President Biden's plan to expand the ACA, including increasing tax-credit eligibility by about half, will add less than half again as many percentage points to the marginal rate in the U.S.

\section{V.A. More generous premium tax credits}

The original ACA set premium tax credits as $0.7 M-\pi(Y) Y$, where $M$ denotes expected medical expenses (in the actuarial sense, including loadings), $Y$ denotes family income, and $\pi(Y)$ is the ACA's cap schedule. Vice President Biden proposes to change the $0.7 M$ to $0.8 M$, which is described as benchmarking against the premiums from gold plans rather than silver plans. For a married family of four, head aged 43, that additional subsidy would be $\$ 1718$ per year conditional on eligibility and participation. ${ }^{35}$ Because the $\$ 1718$ is after-tax dollars, it amounts

\footnotetext{
${ }^{35}$ The average age of head for married nonelderly families on ESI in 2015 was 43 . The subsidy amount is calculated for plan year 2015, based on Mulligan (2015, Table 4.3).
} 
to five percent of the compensation of the median worker with employer-sponsored insurance (ESI). ${ }^{36}$ Ignoring for the moment any eligibility expansion, this increase in the implicit full-timeemployment tax (FTET) rate applies to 29 percent of employed nonelderly household heads and spouses and therefore, among nonelderly household heads and spouses, increases the average marginal tax rate on the FTET margin by about 1.4 percentage points (of compensation), as shown in Table 8. ${ }^{37}$ This is the majority of the combined work disincentives in Vice President Biden's plans for the ACA.

The same provision increases the average marginal tax rate on income for families participating in ACA plans by about three percentage points. Assuming this group to be six percent of nonelderly household heads and spouses (as it was in 2016), this channel of new incentives adds about 0.2 percentage points to the average marginal labor income tax rate among non-elderly household heads and spouses.

\section{V.B. Expanded Eligibility}

The original ACA limited eligibility for premium tax credits to families with incomes with less than 400 percent of the federal poverty line (FPL). Vice President Biden would eliminate this limit, with the premium tax credit gradually phased out at an 8.5 percent marginal rate.

This limit affects two of the labor market distortions from the ACA: the implicit income tax and the implicit FTET. In terms of the implicit income tax, the limit created a "cliff" or "hole" in the household budget constraint where a family participating in the exchange could have more money to spend by keeping their income below the limit. Vice President Biden's plan would encourage the earning of income for exchange families that would otherwise be keeping their income below the limit, while discouraging the earning of income among families higher up in the phase-out range. We treat these two effects as exactly offsetting. ${ }^{38}$

\footnotetext{
${ }^{36}$ Mulligan (2015, Figure 4.2).

${ }^{37}$ Mulligan (2015, Table 4.1).

${ }^{38}$ The taxes required to finance the additional premium tax credits are counted on the tax side of our analysis of the Biden economic plan.
} 
However, the limit also affects the full-time employment tax, which is the incentive for a fulltime worker at an employer offering coverage (which is the large majority of employers of fulltime workers) to leave that employer or switch to a part-time position. The FPL limit was discouraging that behavior. We approximate the FTET disincentive of removing the limit as increasing the eligibility threshold from 400 percent FPL to 550 percent of FPL, which moves about 15 percent of non-elderly household heads and spouses from ineligible to the group of employees that are ineligible only due to full-time employment status. ${ }^{39}$ We assume that they value their subsidy at $\$ 2,000$ (after-tax dollars), which is less than a third of Mulligan’s (2015) estimate of the average subsidy value for families satisfying the original ACA income criteria. $\$ 2,000$ is about 2 percent of the income of a household with income in the 400-550 percent FPL range.

\section{V.C. Public Option}

Candidate Biden proposes that the federal government offer a "public option" plan on the ACA exchanges. Although Vice President Biden did not provide details, we assume that the public option will be relatively attractive for a significant fraction of consumers of ACA plans. These consumers will thereby find ACA subsidies to be more valuable and/or more generous. Assuming that this additional value is, on average, equal to 8 percent of the full premium, the public option adds 0.6 percentage points to the average rate of FTET. ${ }^{40}$

\section{V.D. Medicare buy-in}

Candidate Biden proposes a Medicare buy-in for persons age 60-64. To be conservative, we do not calculate any additional disincentive for those age groups beyond what we capture with the public option.

\footnotetext{
${ }^{39} 76$ percent of non-elderly working household heads and spouses work for an ESI employer (Mulligan 2015, Table 4.1). 83 percent of them cannot obtain ESI through a spouse. Kaiser Family Foundation (2020) shows the 2018 income/FPL distribution of nonelderly with employer coverage to have a density of about 0.00155 per FPL percentage point in the neighborhood of 400 percent of FPL. My 0.15 estimate is $0.00155 *(550-400) * 0.76 * 0.83$. ${ }^{40}$ Mulligan (2015, Table 5.4). The addition to the marginal income tax rate is negligible. If the public option were attractive enough, it could induce a massive number of employers to drop coverage, which in the limit would effectively eliminate the FTET from premium tax credits and replace it with (a) an implicit income tax at 8.5 percent rate and (b) an employer penalty for all full-time workers equal to about 10 percent of compensation at the median. This limiting outcome has more than double the labor-market disincentives that the original ACA had.
} 


\section{V.E. Average marginal labor income tax rates}

Moving persons from full-time work to no work or to part-time work are important margins along which workers reduce their labor income in the short run. Based on Mulligan's (2015) findings, we assume that these margins are 95 percent of changes in labor income with the other five percent being reductions in hours within the full- and part-time categories. The personweighted overall marginal income tax rate is thereby increased 95 percent of the three increases in the FTET rate plus the 0.2 increase in the person-weighted marginal income tax rate from removing the 400 percent FPL cap. This totals 2.4 percentage points. Due to the fact that these disincentives are imposed on workers with less than average productivity, we assume that the income-weighted disincentives are 71 percent of the person-weighted disincentives (Mulligan 2015, Table 8.3) and therefore 1.7 percentage points. These are the bottom-line results shown in Table 8.

\section{Trade Policy and Infrastructure}

The Trump Administration imposed new tariffs on imported goods during 2018 and 2019. Like other taxes on consumer goods, tariffs on consumer goods add to the labor wedge. Tariffs on investment goods add to the cost of capital. Our model of the economic impact of the Biden agenda reflects these facts, including more tariffs in the baseline (Trump) than under Biden's agenda. Moreover, the welfare costs per dollar of revenue from tariffs and other taxes are not trivial in our model because they fall on top of many other significant taxes. ${ }^{41}$

As with other taxes, the contribution of tariffs to labor and intertemporal wedges depends on the statutory rate and the size of the tax base. In 2019, the trade-weighted average tariff rate was 1.4 percentage points above its average from 2001-17 (Ikenson 2020). With imports only fifteen percent of national spending, the contribution of new tariffs to the 2019 wedges is small by comparison with several of the tax and regulatory policies examined elsewhere in this paper. The long-term effect of the new trade policy is not clear. According to the President's Budget

\footnotetext{
${ }^{41}$ Often models of the welfare effect of tariffs hold constant aggregate factor supplies and thereby miss some of the significant welfare costs of tariffs.
} 
(Office of Management and Budget 2020), the tariffs will return to the pre-2018 average in the long run and therefore not contribute to tax wedges in the long run.

Given the overlap in both candidates' trade policy platforms, it is difficult to identify concrete differences. To be conservative as to the impact of Vice President Biden's agenda, we assume that half (rather than none) of the additional tariffs present in 2019 will remain in the long run in the baseline. We further assume that the breakdown of tariffs between consumption and investment goods is roughly in line with spending generally so that they add the same number of percentage points to both the marginal tax rate on labor and on capital. Based on the statutory rates cited above, that is 0.12 percentage points, which corresponds to about $\$ 20$ billion of static revenue. ${ }^{42}$ This is entered in Table 2 as "End Trump tariffs." As with the regulatory wedges, the tariffs are treated as multiplicative with the wedges from the tax code.

The tariff contributions to tax wedges shown in Table 2 are one or two orders of magnitude less than all of the other entries, except for the labor wedge created by applying the full OASDI rate to earnings over $\$ 400,000$. In this light, new tariffs apparently contribute in greater proportion to policy discussions than to tax wedges. Our analysis does not account for other potential costs of the trade policy change: retaliatory tariffs on U.S. exports, domestic production interruptions due to higher tariffs on intermediate goods (Bellora and Fontagné 2019), or the costs of uncertainty created by trade policy changes (Handley and Limao 2017), and so may represent an underestimate of costs from the policy change. ${ }^{43}$

Both President Trump and former Vice President Biden plan to allocate significant amounts of federal spending to rebuilding roads and airports. ${ }^{44}$ In other words, federal infrastructure plans are also in the baseline and thereby, to a first approximation, difference out for the purpose of calculating the impact of Vice President Biden's agenda. We expect that federal spending on infrastructure would be less productive - fewer miles of road, etc., per federal dollar - under

\footnotetext{
${ }^{42}$ This rate is calculated as the extra statutory tariff rate times 2017 imports of goods and services divided by national income.

${ }^{43}$ If tariffs are policy in the steady state, perhaps there is not uncertainty about them in the long run.

${ }^{44}$ Vice President Biden's plans for energy infrastructure investment are part of our analysis of climate and energy policy. Our analysis accounts for both the opportunity costs of those investments and the benefits in terms of adding capacity for generating electricity and shifting the mix of generation toward renewables.
} 
Vice President Biden's agenda due to additional labor and environmental regulation. We do not separately count the efficiency effect in order to be conservative and to avoid double counting the impact of labor regulation noted previously.

\section{Assessing Costs Along a Transition}

This paper estimates the long-run costs of Vice President Biden's economic agenda, with summary statistics reported in Table 9. In doing so, it is worth at least a conceptual discussion of costs along the transition, which is our purpose in this section.

First, the economic experience or political changes along the transition may change the long-run policy goal. An example of this is in the renewable electricity generations pace. Vice President Biden originally proposed a target of 80 percent of generation from carbon-free sources, but later amended the platform to zero carbon-based sources (Dennis and Grandoni 2020). Our estimates are analogous to the first long-run goal, but are conservative relative to the second goal. To the extent that the goalposts move as a policy is developed, our estimates are calibrated to the current proposals. In principle, the policy goals might become more or less ambitious, meaning our cost estimates are too low or too high relative to realized costs.

Second, the time path of the transition may affect the costs that are incurred. Sticking with the renewable electricity example, Vice President Biden originally proposed the 80 percent renewables target by 2050, but later accelerated the timeline to achieve zero carbon emissions by 2035. Moving the goalposts is one thing, but accelerating the timetable may also affect our estimates. In macroeconomics, this is often referenced as “investment adjustment costs" (see the review by Chirinko 1993). A faster transition will not be less costly than a slower transition. Achieving 80 percent of generation from renewables by 2035 will not be less costly than achieving the same goal by 2050. Hitting the same target by 2030 would not be less costly than by 2035. What does differ in that case is the accrual of benefits, which we have not addressed here. 
Third, even without adjustment costs and time-invariant policy parameters, the economic effects of new policy vary over time because capital is inelastically supplied in the short run while elastically supply in the long run. In our calibration of the neoclassical growth model, the transition to a lower-labor steady state involves a short-run dip of labor below its long-run value that dissipates as the capital stock approaches its new lower level. For example (and ignoring population growth), if the tax elements of Vice President Biden's agenda were to take effect immediately, FTEs would be 3.2 million less in the long run but as much as 4.6 million less during the transition when investment is especially depressed.

\section{Conclusions}

We reach three key conclusions as to the effects of Vice President Biden's full policy agenda on tax and productivity wedges. First, transportation and electricity will require a lot more inputs (including 1.3 million net additional energy workers) to produce the same outputs due to Vice President Biden's ambitious plans to further cut the nation's carbon emissions. Because these industries are a nontrivial share of the overall economy, that means one or two percent less total factor productivity overall. These affects would be significantly larger - likely dwarfing the (nontrivial) rest of the agenda - and speculative if the energy goals are taken literally, which we do not. The costs would also be concentrated geographically. Second, labor wedges are increased by proposed changes to regulation as well as to the ACA. Our quantitative findings for the ACA should be no surprise given what had been found for previous efforts in the U.S. and other countries to expand health insurance coverage. Third, Vice President Biden's agenda reduces capital intensity by increasing average marginal tax rates on capital income.

We then assume, as many growth models do, that the supply of capital is elastic in the long run to its after-tax return and that the substitution effect of wages on labor supply is nontrivial. We

conclude that, in the long run, Vice President Biden's full agenda reduces full-time equivalent employment per person by about 3 percent, the capital stock per person by about 15 percent, real GDP per capita by more than 8 percent, and real consumption per household by about 7 percent. Relative to the CBO's 2030 projections for these variables, this suggests there will be 4.9 million 
fewer employed individuals, \$2.6 trillion less GDP, and \$1.5 trillion less consumption in that year alone. Median household income in 2030 would be $\$ 6,500$ less. The projections are conservative in terms of the sensitivity of wages and average productivity to the after-tax share of capital income (Barro and Furman 2018 assume about twice as much), our treatment of business and labor regulation as redistributive versus resource using, and the ambitions of Biden's agendas for health insurance, energy, and climate. On the other hand, the economic effects could be less if the agenda is only partially implemented. 


\section{Appendix I: Cost of Capital Methodology}

\section{Overview}

When computing the cost of capital, several modeling decisions must be made. Among these are whether to assume a constant debt-to-asset ratio or constant debt-to-value ratio, whether to compute the cost of capital at time $t$ based only on time- $t$ policy (in which firms naively ignore legislated future policy changes), and how to treat the relationship between the required rate of return faced by the firm and individual income taxes on investment income.

The cost of capital is defined as the pretax rate of return required to generate a breakeven after-tax return. That the activity on which this return is generated can be somewhat ambiguous. It can be thought of as a project, as some small independent investment, as the marginal investment on a project, or as the marginal investment for an entire firm.

The general form of cost of capital equations is given by equation (1).

$$
\rho=\frac{1-Z-F}{1-\tau}(r-\pi+\delta)-\delta
$$

In this equation, $r$ is the nominal required rate of return on assets, $\pi$ is the inflation rate, $\delta$ is the economic depreciation rate. $\tau$ is the business-level tax rate (the corporate tax rate for $\mathrm{C}$ corporations, or the average owner-level marginal tax rate on business income for pass-through businesses), $Z$ is the present value of the tax shield from capital cost recovery (depreciations deductions, expensing and investment tax credits), and $F$ is the tax shield from debt financing.

Note that the representation of the tax shield from debt financing in equation (1) is based on an assumption of a constant debt-to-asset ratio. A common alternative assumption is a constant debt-to-value ratio, in which case $D_{t}$ is dropped from the equation and the flow value of the debt tax shield is subtracted from $r$. This formula is given in equation (2), where $\Delta$ is the debt-to-value ratio and $r_{d}$ is the nominal interest rate on debt. Under economic depreciation, these two methods are equivalent, although they are not under under methods of capital cost recovery. Subsection 1.3 describes the distinction in greater detail, as well as the complications resulting from the use of a constant debt-to-value ratio when tax rates are not constant.

$$
\rho=\frac{1-Z}{1-\tau}\left(r-\Delta \tau r_{d}-\pi+\delta\right)-\delta
$$

Versions of this equation can generally be derived in four ways: discrete time over two periods, discrete time with an infinite horizon, continuous time flow, and continuous time over an infinite horizon. Discrete time in two periods assumes that the firm invests and begins to claim capital cost recovery deductions at time zero, realizes income at time 1 , and disinvests the undepreciated (amount) at time 1 . Discrete time with an infinite horizon also assumes that the firm invests and begins to claim capital cost recovery deductions at time zero, and it realizes income beginning at time 1 and thereafter in proportion to the value of capital, with the real value of capital depreciating at a constant geometric rate. If the underlying parameters and tax rules are constant, these two discrete time methods are equivalent.

In continuous time, the flow version assumes that the firm's opportunity cost of investment is $(1-Z)(r-$ $\pi+\delta$ ), namely that the investment must generate an after-tax rate of return $r-\pi$, loses value at the constant continuous time rate $\delta$, and receives the tax shield $Z$ from capital cost recovery. It must in turn generate the pretax gross profit $\rho+\delta$, which gets taxed at rate $\tau$. These give the result that $(\rho+\delta)(1-\tau)=(1-Z)(r-\pi+\delta)$. In the infinite horizon continuous time version, an investment of unit 1 generates a continuous-time gross profit rate $\rho+\delta$, applied to the contemporaneous value of the undepreciated capital $e^{-\delta t}$. It pays taxes 
on these profits, and also receives a tax shield from capital cost recovery deductions. If the underlying parameters and tax rates are constant, these two continuous time methods are equivalent.

However, if tax rates are not constant, then some of these equations break down. In particular, the biggest challenge to this occurs because all of these equations use the present value of tax depreciation deductions (or other capital cost recovery method). With a constant tax rate, the present value of the tax shield from capital cost recovery is simply the tax rate multiplied by the present value of those deductions (ignoring investment credits). However, with tax rates that are not constant (as under current law for pass-through business income), this is not true.

The rest of this document proceeds as follows. The following section provides equations for capital cost recovery, including different forms of depreciation, expensing and investment tax credits. We then derive the infinite-horizon continuous-time cost of capital equations, allowing for time-varying or uncertain tax rates. This is particularly relevant for modeling the baseline cost of capital, as the QBI pass-through exclusion is set to expire in 2026. We then derive the present value of the tax shield from debt financing under constant debt-to-value and debt-to-asset ratios, and we show the time-inconsistency problems that arise from a debtto-asset ratio under time-varying tax rates. We also consider the potential complications arising from the taxation of investment income for households, and we provide equations for the effective average tax rate on projects with supernormal returns, which are relevant for international investment decisions and the implications of rules for international tax policies. We also show how to include state and local taxes in this formulation.

\section{Capital Cost Recovery}

We define $Z$ as the present value of the tax shield from capital cost recover. Methods of capital cost recovery consist of various methods of depreciation (deductions for tax purposes), expensing (immediate deduction of the invested amount), and investment tax credits.

Let $D$ denote the present value of the deductions for capital cost recovery. Under expensing, the full amount of the investment is immediately deducted, which gives $D=1$. Under economic depreciation (when deductions for tax purposes equal actual depreciation of the asset), the present value is

$$
D=\int_{0}^{\infty} \delta e^{-(r-\pi+\delta) t} d t=\frac{\delta}{r-\pi+\delta}
$$

Under straight-line depreciation, the deductions for the asset are spread over $L$ years, with a fraction $1 / L$ deducted each year (with adjustments made for timing of the investment during the year). This produces the present value

$$
D=\int_{0}^{L} \frac{1}{L} e^{-r t} d t=\frac{1}{r L}\left(1-e^{-r L}\right)
$$

Under accelerated depreciation - also known as declining balance depreciation - the firm uses declining balance depreciation at rate $n / L$ (where $n$ is 2 for $200 \%$ declining balance and 1.5 for $150 \%$ declining balance), and switches to straight-line depreciation at time $L\left(1-\frac{1}{n}\right)$. The present value obeys the following formula.

$$
\begin{aligned}
D & =\int_{0}^{L(1-1 / n)} \frac{n}{L} e^{-\frac{n}{L} t} e^{-r t} d t+\int_{L(1-1 / n)} \frac{1}{L-L(1-1 / n)} e^{1-n} e^{-r t} d t \\
& =\frac{n}{r L+n}\left(1-e^{-\left(\frac{r l}{N}+1\right)(n-1)}\right)+\frac{n}{r L} e^{1-n-r L}\left(e^{r L / n}-1\right)
\end{aligned}
$$

The equations above omit bonus depreciation, in which the firm may immediately expense a share $b$ of the investment. Including bonus depreciation requires computing $D$ as the weighted average of 1 and the present value of the deductions, using $b$ and $1-b$ as the respective weights.

Let $c$ be the effective credit rate, essentially the product of the statutory rate and the eligible fraction of investment, although the true computations are more complicated. The most common of these is the Credit For Increasing Research Activities (henceforth, the R\&D tax credit), although there are also credits for renewable energy investments. Note that the relevant law intends to limit the ability of firms to doublecount the investment tax credit and expensing. Firms must either reduce the depreciable basis by the amount 
of the credit, or they can reduce the credit by the product of the credit and the corporate tax rate. Although additional complications and rules render these methods not equivalent, with most firms electing the latter, they are equivalent in a simple mathematical framework. Under current policy, the R\&D tax credit may be claimed immediately, but beginning in 2022 it must be amortized over five years. Let $\tilde{L}$ denote the amount of time over which the credit must be amortized. The entire tax shield from capital cost recovery is

$$
Z=\tau(1-c)(b+(1-b) D)+\frac{c}{r \tilde{L}}\left(1-e^{-r \tilde{L}}\right)
$$

Note that immediate claiming of the R\&D tax credit can be achieved by taking the limit as $\tilde{L} \rightarrow 0$.

When tax rates are not constant over time, care must be taken when computing the present value of the tax shield from accelerated depreciation.

\section{Time-Varying and Uncertain Tax Rates}

When tax rates are not constant over time, the cost of capital equations should reflect that firm investment decisions are forward-looking and should include anticipated tax changes. A number of tax provisions from the 2017 tax act are scheduled to expire in 2025 (the individual income tax provisions, except for chained CPI indexing), and the international tax provisions become less generous in 2026. (The GILTI exclusion decreases from $50 \%$ to $37.5 \%$, and the FDII exclusion decreases from $37.5 \%$ to $21.875 \%$.)

In a general case, we allow tax rates to vary arbitrarily over time. In this situation, the after-tax rent on a project is

$$
\begin{aligned}
R & =-1+\int_{0}^{\infty}(p+\delta) e^{-(r-\pi+\delta) t} d t-\int_{0}^{\infty} \tau_{t}\left((p+\delta) e^{(\pi-\delta) t}-d_{t}-\Delta r_{d} e^{(\pi-\delta) t}\right) d t \\
& =-1+Z+F+(p+\delta) \int_{0}^{\infty}\left(1-\tau_{t}\right) e^{-(r-\pi+\delta) t} d t \\
& =-1+Z+F+\frac{p+\delta}{r-\pi+\delta}(1-T)
\end{aligned}
$$

where $T$ is the time-averaged tax rate faced by the firm, weighted by the value of the asset over time.

$$
T \equiv \int_{0}^{\infty} \tau_{t}(r-\pi+\delta) e^{-(r-\pi+\delta) t} d t
$$

In these equations, $p$ is the profit rate of the project. For convenience, $d_{t}$ refers to the tax depreciation deductions, although this can be augmented to incorporate investment tax credits.

The cost of capital is obtained by setting $R=0$ and solving for $p$ (and referring to it using the notation $\rho)$. This gives the general form of the cost of capital:

$$
\rho=\frac{1-Z-F}{1-T}(r-\pi+\delta)-\delta
$$

In the case of a known future change in tax rates (such as under current law), the terms $Z, F$ and $T$ can be computed separating the integration. If firms are uncertain about future tax rates (e.g. assume some probability that provisions set to expire will be extended), each term $Z, F$ and $T$ can be computed using expected tax rates, as each of these is linear in the tax rates. The cost of capital is then computed using the expected values of $Z, F$ and $T$; note that this is not equivalent to computing the expected value of $\rho$, as $\rho$ is nonlinear in tax rates.

If tax rates are constant, then the infinite-horizon equation reduces to the flow rate version. If not, then longer-lived assets (those with low $\delta$ ) are more exposed to future tax rate changes. Moreover, because deductions for depreciation under the modern accelerated cost recovery system are generally front-loaded relative to economic depreciation (as is expensing), relatively more of these gross profit from the project it subject to the future tax rates than the deductions. 


\section{Debt Financing}

Recall that the relationship between the required return on assets $r$ and the discount rate including the interest deduction $r_{w}$ is $r_{w}=r_{a}-\Delta r_{d} \phi \tau$, where $\Delta$ is the debt-to-value ratio (or debt-to-asset ratio, depending on desired assumptions), $r_{d}$ is the nominal interest rate on debt, and $\phi$ is the share of interest eligible for the net interest deduction (on a marginal investment).

There are generally two approaches to modeling the distortion from interest deductibility. One approach includes interest deductibility in the discount rate, using $r_{w}$ to discount profits and the tax shield from depreciation deductions. The cost of capital under this approach is

$$
\rho_{1}=\frac{1-Z_{1}}{1-\tau}\left(r_{w}-\pi+\delta\right)-\delta
$$

where $Z_{1}$ refers to the present value of the tax shield from capital cost recovery when using $r_{w}$ to discount depreciation deductions.

Another approach, used in the subsections above, discounts using the required return on assets, and computes the present value of the tax shield from interest deductibility, with

$$
\rho_{2}=\frac{1-F-Z_{2}}{1-\tau}(r-\pi+\delta)-\delta
$$

where $Z_{2}$ is the present value of the tax shield from capital cost recovery when using $r$ to discount depreciation deductions. The present value of the tax shield from debt financing is

$$
F=\int_{0}^{\infty} \Delta r_{d} \phi \tau e^{-(r-\pi+\delta) t} d t=\frac{\Delta r_{d} \phi \tau}{r-\pi+\delta}
$$

In the following discussion, I will refer to the approach of discounting with a rate that includes the NID tax shield as the "discounting method" to the approach of separately modeling the present value of the NID tax shield as the "present value method".

The difference between the discounting method and present value method originates in a difference in assumptions. The discounting method assumes a constant debt-to-value ratio, and the present-value method assumes a constant debt-to-asset ratio. Although either of these assumptions is potentially valid, the results are not identical.

When tax rates are constant, these two methods can be compared relatively easily. The difference between them is given by

$$
\rho_{1}-\rho_{2}=\frac{1}{1-\tau}\left(Z_{2}(r-\pi+\delta)-Z_{1}\left(r_{w}-\pi+\delta\right)\right)
$$

If depreciation deductions for tax purposes are based on economic depreciation, these two methods are equivalent, with $\rho_{1}=\rho_{2}$. Intuitively, using economic depreciation causes tax deductions to move in proportion to residual asset value (as income does), and so the asset amount and project value (on a breakeven project or marginal investment) are exactly equal. However, in general this is not the case. Under expensing, the difference is

$$
\text { Expensing: } \quad \rho_{1}-\rho_{2}=\frac{\Delta r_{d} \phi \tau^{2}}{1-\tau}
$$

As MACRS depreciation is generally more front-loaded than economic depreciation, a constant debt-tovalue ratio assumption will (in general) produce a higher cost of capital than a constant debt-to-asset ratio assumption.

However, when tax rates are not constant over time, these comparisons are not valid. With nonconstant tax rates, the present value method remains relatively easy to solve for, with

$$
F=\int_{0}^{\infty} \Delta r_{d} \phi \tau_{t} e^{-(r-\pi+\delta) t} d t=\frac{\Delta r_{d} \phi T}{r-\pi+\delta}
$$

where $T$ is the time-averaged tax rate derived in the previous section. 
On the other hand, the discounting method becomes substantially more complicated with time-varying tax rates, as the discount rate used then varies with the tax rate, which induces time-inconsistent discounting. The after-tax rent is

$$
R=-1+\int_{0}^{\infty}(p+\delta) e^{(\pi-\delta) t} \beta_{t} d t-\int_{0}^{\infty} \tau_{t}\left((p+\delta) e^{(\pi-\delta) t}-d_{t}\right) \beta_{t} d t
$$

where the discount factor applied to time $t$ cash flows is

$$
\ln \beta_{t}=-\int_{0}^{t}\left(r-\Delta r_{d} \phi \tau_{s}\right) d s
$$

The present value of the tax shield from capital cost recovery now also depends on time-varying or uncertain tax rates, which complicates its calculation. Under this framework, closed-form solutions are far more complicated, although they can be obtained.

\section{Investor-Level Taxes}

For taxes on investment income, let any variable $s_{f}^{o}$ refer to the return to savers that invest through asset type $f$ (debt, equity), where $o$ denotes the form of saving. The form of saving depends on the type of investor and account, including: direct investment by individuals or households; investment by individuals through tax-preferred accounts; investment by nontaxable entities such as pension funds and endowments; foreign investors; and investment by other taxable businesses, in particular financial institutions. All of these forms of saving are relevant for corporate equity and debt financing, but pass-through equity is entirely owned by taxable individuals (and taxed accordingly), and pass-through debt is largely provided by taxable financial institutions.

Note that the expected return to saving is only subject to tax (in present value) if the savings are held in fully taxable form, such as by individuals outside of tax-preferred savings vehicles and to for-profit institutional investors, such as banks and hedge funds.

The interest rate on debt $r_{d}$ can be estimated using data, and the required rate of return on corporate equity $r_{e}$ can be estimated using an equity premium over the risk-free rate. Using these, the required return on assets is $r=\Delta r_{d}+(1-\Delta) r_{e}$.

Using this approach, it is possible to compute after-tax returns to savers from marginal investments. However, a complication arises when comparing two policy categories, namely that the equilibrium required returns on debt and equity may depend on investor-level taxes. Ignoring this dependency creates the appearance that policies that change after-tax returns to savers would have no effects on investment if investment responses are modeled only using the cost of capital with required returns on debt and equity held constant. These effects should be managed through a general equilibrium model that determine required returns on debt and equity using investor-level taxes. As we use a general equilibrium model when estimating investment responses, we omit any response in required rates of return when presenting METRs and EATRs.

We also present the METTRs, which represent the entire tax wedge between the pre-tax cost of capital and the average after-tax return to savers $s$.

$$
M E T T R=\frac{\rho-s}{\rho}
$$

The average after-tax return to savers is a weighted average of the after-tax returns to debt investors $s_{d}$ and to equity investors $s_{e}$, where the debt-equity split (debt financing share $\Delta$ ) varies by industry.

$$
s=\Delta s_{d}+(1-\Delta) s_{e}
$$

The after-tax return to lenders is

$$
s_{d}=\omega_{d, t} r_{d} *\left(1-\tau_{i}\right)+\left(1-\omega_{d, t}\right) r_{d}-\pi
$$

where $\omega_{d, t}$ is the share of debt held in taxable form, and $\tau_{i}$ is the average tax rate on interest income. The after-tax return to equity investors depends on firm type and the form of the realization of the equity value. 
For pass-through businesses, the return to equity is not subject to a second layer of tax, although it is for $\mathrm{C}$ corporations. Thus for pass-through businesses, $s_{e}=r_{e}-\pi$, and for $\mathrm{C}$ corporations, the after-tax return is given by

$$
s_{e}=\omega_{e, t}\left(m r_{e}\left(1-\tau_{d}\right)+(1-m)\left(s_{c g}+\pi\right)\right)+\left(1-\omega_{e, t}\right) r_{e}-\pi
$$

where $\omega_{e, t}$ is the share of equity held in taxable form, $m$ is the share of the equity return paid out as dividends, $\tau_{d}$ is the average tax rate on dividend income (computed using Tax-Calculator), and $s_{c g}$ is the after-tax return through capital gains. This return to capital gains is given by

$$
\begin{aligned}
s_{c g}+\pi= & w_{s c g} r_{e}\left(1-\tau_{s c g}\right)+w_{l c g}\left(\frac{1}{h_{l c g}(1-m)}\right) \ln \left(e^{h_{l c g}(1-m) r_{e}}\left(1-\tau_{l c g}\right)+\tau_{l c g}\right) \\
& +\left(1-w_{s c g}-w_{l c g}\right)\left(\frac{1}{h_{x c g}(1-m)}\right) \ln \left(e^{h_{x c g}(1-m) r_{e}}\left(1-\tau_{x c g}\right)+\tau_{x c g}\right)
\end{aligned}
$$

In this equation, $w_{s c g}$ and $w_{l c g}$ are the shares of capital gains realized as short-term and long-term gains, respectively, with the remainder held until death. $\tau_{s c g}$ and $\tau_{l c g}$ are the average tax rates on short-term and long-term capital gains (computed using Tax-Calculator), and $\tau_{x c g}$ is the tax rate on capital gains at death. Both long-term gains and gains held until death are adjusted for the holding periods $h_{l c g}$ and $h_{x c g}$.

We use the following parameterization for the relevant shares. These weights are based on those from CBO (2014).

Table 1: Allocation of Debt and Equity Holdings

\begin{tabular}{llc}
\hline Parameter & Description & Value \\
\hline$\omega_{d, t}^{c}$ & Taxable share of corporate debt & $52.3 \%$ \\
$\omega_{d, t}^{p}$ & Taxable share of pass-through debt & $76.3 \%$ \\
$\omega_{e, t}$ & Taxable share of corporate equity & $57.2 \%$ \\
$m$ & Dividend payout share & $44 \%$ \\
$w_{s c g}$ & Capital gains share realized short-term & $3.4 \%$ \\
$w_{l c g}$ & Capital gains share realized long-term & $49.6 \%$ \\
$h_{l c g}$ & Holding period for long-term capital gains & 10 years \\
$h_{s c g}$ & Holding period for gains held until death & 30 years \\
\hline
\end{tabular}

\section{Effective Average Tax Rates}

We now consider potential effects of tax changes on international investment. The international investment response is an extensive margin effect in which tax changes affect firm decisions on which countries to locate investments that generate supernormal returns. We model these incentives using effective average tax rates (EATRs). As in the cost of capital derivations, the after-tax rent on a project is given by

$$
R=-(1-Z-F)+\frac{p+\delta}{r-\pi+\delta}(1-T)
$$

Recall that $T$ is the average statutory rate faced by the firm over the life of the project. Whereas we set $R=0$ to compute the cost of capital, here we allow the project rent to be positive, with an income rate $p$.

To compute the EATR, we require two more terms: the rent on the project in the absence of business taxes $R^{*}$, and the present value $P$ of the income stream from the project.

$$
\begin{gathered}
R^{*}=-1+\int_{0}^{\infty}(p+\delta) e^{-(r-\pi+\delta) t} d t=\frac{p-(r-\pi)}{r-\pi+\delta} \\
P=\int_{0}^{\infty} p e^{-(r-\pi+\delta) t} d t=\frac{p}{r-\pi+\delta}
\end{gathered}
$$

The EATR is given by

$$
E A T R=\frac{R^{*}-R}{P}
$$


Substituting in the solutions above and rearranging gives the following representation of the EATR.

$$
E A T R=\left(\frac{p-\rho}{p}\right) T+\left(\frac{\rho}{p}\right) M E T R
$$

The EATR is a weighted average of the average statutory rate rate and the METR, where the weight on the average statutory tax rate is the share of the project income rate in excess of the cost of capital.

When considering international investment incentives for projects with supernormal returns, it is critical to incorporate the effects of the Foreign Derived Intangible Income (FDII) exclusion and the Global Intangible Low-Taxed Income (GILTI) provision. Each of these provisions allows a firm to exclude part of income in excess of $10 \%$ of tangible assets, with tangible assets depreciated using the alternative depreciation system. Thus for a domestic project eligible for FDII (i.e. that sells to foreign purchasers), the EATR becomes

$$
\operatorname{EATR}=\left(\frac{\rho}{p}\right) \operatorname{METR}+\left(\frac{0.1 \mathbb{1}_{\text {tan }}-\rho}{p}\right) T+\left(\frac{p-0.1 \mathbb{1}_{\text {tan }}}{p}\right) T\left(1-\theta_{F D I I}\right)
$$

In this expression, $\mathbb{1}_{\text {tan }}$ is an indicator for whether the relevant asset is depreciable (equipment or structures) and $\theta_{F D I I}$ is the exclusion rate for FDII (37.5\% under current policy, and $21.875 \%$ beginning in 2026).

For a foreign project, GILTI is assessed on $50 \%$ of income in excess of $10 \%$ of tangible assets, with a credit for $80 \%$ of foreign taxes. Thus under a $21 \%$ statutory US corporate tax rate, a firm has tax liability under GILTI if and only if the foreign tax rate is under $13.125 \%$. Thus the EATR is as follows.

$$
E A T R=\left(\frac{\rho_{f}}{p}\right) M E T R_{f}+\left(\frac{p-\rho_{f}}{p}\right) \tau_{f}+\left(\frac{p-0.1 \mathbb{1}_{\text {tan }}}{p}\right) \max \left\{T\left(1-\theta_{G I L T I}\right)-0.8 \tau_{f}, 0\right\}
$$

In these equations, $\rho_{f}$ and $M E T R_{f}$ refer to the cost of capital and METR in the foreign country, computed using full interest deductibility, the alternative depreciation system and the foreign tax rate.

\section{State and Local Taxes}

When measuring the full burden of capital taxes, it is important to include the burdens from state and local taxes. These generally take three forms: taxes on business income, taxes on investment income, and property taxes.

For $\mathrm{C}$ corporations, state and local taxes are fully deductible. Accordingly, the tax rate used for $\mathrm{C}$ corporations is

$$
\tau=\tau_{f}+\tau_{s}\left(1-\tau_{f} \tau_{f}\right)
$$

where $\tau_{f}$ is the federal tax rate, $\tau_{s}$ is the state and local tax rate, and the interaction terms adjusts for deductibility of state and local taxes.

For purposes of state and local corporate taxes, only top tax rates matter, and it is difficult to adjust for decisions by corporations to headquarter in lower-tax jurisdictions. We also lack sufficient data to estimate this properly. Given these challenges, we use a conservative rate of $5 \%$, although most states have top statutory corporate tax rates higher than this (Cammenga 2020). ${ }^{1}$

For state and local taxes on pass-through business income, these taxes are levied at the level of the owner's business income. Consequently, limits on the deductibility of state and local taxes, in particular the $\$ 10,000$ SALT cap, raise the impact of state and local taxes on pass-through business tax rates. The tax rate used for pass-through businesses is

$$
\tau=\tau_{f}+\tau_{s}\left(1-\tilde{\tau}_{s}\right)
$$

where $\tilde{\tau}_{s}$ is the weighted average marginal subsidy on state and local taxes paid, estimated using TaxCalculator. Under current law, this subsidy is approximately $0.8 \%$, although with the expiration of the individual income tax provisions it would rise to $13.6 \%$. Tax rates on interest income, dividends, and shortterm and long-term capital gains are similarly adjusted. To obtain estimates of the state and local marginal tax rates, we use estimates from Feenberg \& Coutts (1993), which compute these state tax rates up through

\footnotetext{
${ }^{1}$ Cammenga, Janelle. "State Corporate Income Tax Rates and Brackets for 2020." Tax Foundation, January 2020, https://taxfoundation.org/state-corporate-income-tax-rates-brackets-2020/.
} 
2008. The average rates have remained stable over their sample period, so we use the most recent estimates only. ${ }^{2}$

Finally, we need to augment the relevant equations to allow for property taxes. This is fairly simple, as the cost of capital equation becomes

$$
\rho=\frac{1-Z-F}{1-T}(r-\pi+\delta)-\delta+\tau_{p}(1-T)
$$

where $\tau_{p}$ is the property tax rate. State and local property taxes paid are fully deductible from business income. To estimate the property tax rate, we divide total state and local property tax revenue ( $\$ 526$ billion in $2017^{3}$ ) by total tangible fixed assets in 2017 (\$42,093.4 in 2017, from BEA fixed asset data), which gives a $1.25 \%$ property tax rate on tangible property. We assume a zero property tax rate on intangible property, as it is generally not subject to property taxes and is difficult to value when computing property tax liability.

\section{Data}

We separately compute costs of capital and METRs by fixed asset type (92 asset types), by industry (62 industries) and by firm type (C corporation, $\mathrm{S}$ corporation, sole proprietorship and partnership). We allow the tax rates used to vary by firm type, with the rate for $\mathrm{C}$ corporations as specified by relevant law, and the tax rates for sole proprietorships, partnerships and $\mathrm{S}$ corporations computed using the open-source Tax-Calculator microsimulation model for the individual income and payroll taxes.

To compute weighted averages, we use a breakdown of net stocks of fixed assets by asset type, by industry and by firm type. These are computed using the BEA detailed fixed asset tables, which provide net stocks and investment in fixed assets by asset type and industry. We combine this with BEA data on fixed assets by legal form of organization to split these between corporations, sole proprietorships and partnerships. We use the IRS SOI Tax Stats on returns of active corporations to split corporate assets into those of S corporations and those of $\mathrm{C}$ corporations.

\footnotetext{
${ }^{2}$ Feenberg, Daniel and Elizabeth Coutts. "An Introduction to the Taxsim Model." Journal of Policy Analysis and Management 12 (1), Winter 1993.

${ }^{3}$ https://www.urban.org/policy-centers/cross-center-initiatives/state-and-local-finance-initiative/projects/state-and-localbackgrounders/property-taxes
} 


\section{Appendix II. Sensitivity Analysis}

Table 9 shows how the results are different by excluding various changes in tax rates and productivity. Table 10 shows the same "full agenda” benchmark specification as in Table 9, as well as variations. The next column of the table shows how per capita GDP is depressed somewhat more, and per capita FTEs somewhat less, by treating the effect of business and labor regulations as a use of resources rather than redistribution. The final two columns show results for smaller (a Frisch elasticity of 1/4 rather than 1/2) and larger (1 rather than 1/2) wage elasticities of labor supply, respectively.

The employment effects range from -1.9 percent to -4.6 percent. The GDP effects range from -7.3 percent to -10.3 percent. Two reinforcing economic effects keep these ranges fairly tight in Table 10. First, Vice President Biden’s agenda adds significantly to the cost of capital. Second, as shown in the main text, the sensitivity of wages to the cost of capital depends only on labor's share and the share of the cost of capital in the user cost of capital and therefore does not vary across the columns of Table 10.

As noted in the main text, the elasticity of the long-run wage rate to the after-tax share of capital income depends only on labor's share and the long-run cost of capital's share in the user cost of capital. The latter share is pinned down by the depreciation rate, which is measured in the national accounts, and the long-run after-tax return. We calibrate the after-tax return of 3.59 percent per year to fit a capital-output ratio of 2.5. Another method would be to measure the level of the user cost of capital in the national accounts, which might suggest a higher after-tax return - and thereby long-run wages that are more elastic to taxation - such as that used by Barro and Furman (2018). Our approach was taken to be conservative as to the long-run wage elasticity, which is about half of Barro and Furman's.

In our main analysis of capital taxation, we compared the Vice President Biden proposals to a current policy baseline, which assumes that future legislated tax changes do not occur. These scheduled future changes include the expiration of the individual income tax provisions of the 2017 tax law, the phase-down of bonus depreciation from 2023 through 2027, the reduction in 
the exclusions provided by GILTI and FDII, and the 5-year amortization of the R\&D tax credit beginning in 2022. These future tax hikes were scheduled to satisfy the Byrd rule, but whether Congress will allow these to occur is ambiguous. Most temporary tax cuts are repeated extended or eventually made permanent, and it seems likely that many or most of the temporary provisions of the 2017 tax act will have this same effect.

The sensitivity analysis in Table 11 presents a comparison of the capital tax wedges under alternative assumptions about the extension of temporary tax provisions for 2029. The first column and the last are as in Table 3---the current policy baseline and the Vice President Biden proposals. The second column supposes that the individual income tax changes in the 2017 tax act are made permanent, but that the business tax cuts expire as legislated. This substantially increases the METRs and METTRs, by similar magnitudes. Most of this effect occurs due to the expiration of bonus depreciation, which causes short-lived assets (excluding R\&D expenses) to become subject to standard tax depreciation instead of immediate expensing. Because expensing shields the entire tax burden from taxation (in present value) but tax depreciation does not, this causes the METRs on equipment and short-lived structures to switch from negative to positive. The third column of Table 11 presents the capital tax wedges under current law, which assumes no action by Congress to extend temporary tax provisions. Relative to the scenario of extending only the individual income tax provisions, this modestly increases METRs and METTRs. Relative to current law, Vice President Biden’s proposals increase federal METRs across firm types and asset types (except for $R \& D$ ), although this is partly offset by restoring the deductibility of state and local income taxes. 


\section{Table 1. Policies quantified in this paper}

\section{Tax policies}

Increase the corporate tax rate to $28 \%$

Raise the GILTI tax rate to $28 \%$

Allow TCJA bonus depreciation to phase down Immediately return tax rates on income over $\$ 400,000$ to pre-TCJA levels (top rate of $39.6 \%$ ).

Phase out itemized deductions for taxable income over $\$ 400,000$

Cap itemized deductions at $27 \%$ of value

Phase out the QBI deduction for taxable income over $\$ 400,000$

Tax capital gains over $\$ 1$ million at the top rate of $39.6 \%$

Extend the EITC to those over age 65

Apply the 12.4 percent OASDI payroll tax to earnings above $\$ 400 \mathrm{k}$

Replace deductions for IRA and KEOGH contributions with $26 \%$ credit

Allow other TCJA provisions to expire in 2026

End Trump tariffs

Regulatory policies

Renewable energy for electricity generation

Electrification of the passenger vehicle fleet

Net Neutrality and Internet Privacy

Reinstate CFPB regulations

Reinstate prohibitions on short-term and group insurance plans

Reinstate generic drug approval procedures

Reinstate seven significant labor regulations

Reinstate five other regulations for banking, mining, and farming

Reinstate the individual mandate

Health insurance subsidies

Gold-plan benchmark rather than silver

Remove 400\% FPL cap

Add a public option to ACA plans 


\section{Table 2. Tax and productivity parameters}

By major policy category

\begin{tabular}{lrrrr} 
& \multicolumn{2}{c}{ Labor-income tax rate } & Capital-income & \\
Policy category & Additive & Multiplicative & tax rate & TFP \\
\hline Baseline & $\mathbf{4 8 . 0 \%}$ & $\mathbf{0}$ & $\mathbf{2 4 . 4 \%}$ & $\mathbf{1}$ \\
& \multicolumn{2}{c}{ Biden tax changes } & & \\
& $0.05 \%$ & 0 & $12.5 \%$ & $-0.1 \%$ \\
Tax policy (except ACA) & $2.4 \%$ & 0 & 0 & $0.2 \%$ \\
ACA changes & 0 & $-0.1 \%$ & $-0.1 \%$ & 0 \\
End trump tariffs & & &
\end{tabular}

\begin{tabular}{lrrrr} 
& Biden regulatory changes & & \\
Energy & 0 & $1.0 \%$ & 0 & $-1.8 \%$ \\
CEA 20 & 0 & $1.9 \%$ & 0 & 0 \\
\hline Biden & $\mathbf{5 1 . 9 \%}$ & NA & $\mathbf{3 6 . 9 \%}$ & $\mathbf{- 1 . 7 \%}$ \\
$\quad \%$ impact on after-tax share & $-7.5 \%$ & & $-16.5 \%$ &
\end{tabular}

The policies included in each category are listed in Table 1. Marginal tax rates include implicit taxes from safety-net programs. Each Biden policy either adds to the baseline labor wedge, multiplies the baseline labor wedge, adds to the baseline intertemporal wedge, reduces total factor productivity, or a combination of these. The bottom bold row shows the accumulation of the wedges and TFP changes, with the multiplicative wedges converted to the equivalent additive wedge. The final row shows the percentage change in two after-tax shares associated with moving from baseline to Biden. Our policy simulation with the neoclassical growth model uses the two bold rows.

ACA refers to Affordable Care Act. CEA 20 refers to the sample of 20 regulatory actions analyzed by the Council of Economic Advisers (2020). Sales taxes and additions to the income tax are examples of multiplicative and additive changes to the labor wedge. 
Table 3. Federal tax distortions to investment incentives

\begin{tabular}{|c|c|c|c|c|c|c|c|c|c|}
\hline \multirow{3}{*}{ Marginal Effective Tax Rate (METR) } & \multicolumn{3}{|c|}{2021} & \multicolumn{3}{|c|}{2025} & \multicolumn{3}{|c|}{2029} \\
\hline & Baseline & Biden & Diff & Baseline & Biden & Diff & Baseline & Biden & Diff \\
\hline & & & & & & & & & \\
\hline $\mathrm{C}$ corporations & $-5.2 \%$ & $-7.7 \%$ & $-2.5 \%$ & $-5.0 \%$ & $2.5 \%$ & $7.5 \%$ & $-5.0 \%$ & $7.1 \%$ & $12.0 \%$ \\
\hline S corporations & $-3.4 \%$ & $0.9 \%$ & $4.3 \%$ & $-4.4 \%$ & $10.3 \%$ & $14.7 \%$ & $-4.5 \%$ & $7.6 \%$ & $12.1 \%$ \\
\hline Sole proprietorships & $3.3 \%$ & $9.5 \%$ & $6.2 \%$ & $1.1 \%$ & $14.2 \%$ & $13.1 \%$ & $-0.3 \%$ & $10.2 \%$ & $10.6 \%$ \\
\hline Partnerships & $0.9 \%$ & $3.2 \%$ & $2.2 \%$ & $-2.9 \%$ & $13.1 \%$ & $15.9 \%$ & $-5.0 \%$ & $11.9 \%$ & $17.0 \%$ \\
\hline Equipment & $-11.9 \%$ & $-16.9 \%$ & $-5.0 \%$ & $-12.7 \%$ & $0.2 \%$ & $12.9 \%$ & $-13.2 \%$ & $6.8 \%$ & $20.0 \%$ \\
\hline Structures & $5.3 \%$ & $6.5 \%$ & $1.3 \%$ & $5.2 \%$ & $11.6 \%$ & $6.4 \%$ & $5.1 \%$ & $13.9 \%$ & $8.9 \%$ \\
\hline Residential & $7.8 \%$ & $14.6 \%$ & $6.9 \%$ & $7.8 \%$ & $15.1 \%$ & $7.3 \%$ & $7.8 \%$ & $15.2 \%$ & $7.4 \%$ \\
\hline Intellectual property & $-32.1 \%$ & $-36.8 \%$ & $-4.7 \%$ & $-33.2 \%$ & $-19.1 \%$ & $14.1 \%$ & $-33.8 \%$ & $-20.2 \%$ & $13.6 \%$ \\
\hline All business & $-3.9 \%$ & $-4.9 \%$ & $-1.0 \%$ & $-4.3 \%$ & $4.8 \%$ & $9.1 \%$ & $-4.6 \%$ & $7.8 \%$ & $12.4 \%$ \\
\hline All business, incl. state/local taxes & $10.8 \%$ & $8.8 \%$ & $-2.0 \%$ & $10.4 \%$ & $17.5 \%$ & $7.0 \%$ & $10.2 \%$ & $20.1 \%$ & $10.0 \%$ \\
\hline \multicolumn{10}{|c|}{ Marginal Effective Total Tax Rate (METTR) } \\
\hline C corporations & $10.7 \%$ & $15.2 \%$ & $4.4 \%$ & $11.1 \%$ & $23.2 \%$ & $12.1 \%$ & $11.4 \%$ & $27.4 \%$ & $16.1 \%$ \\
\hline S corporations & $4.0 \%$ & $9.1 \%$ & $5.1 \%$ & $3.0 \%$ & $16.5 \%$ & $13.5 \%$ & $3.1 \%$ & $14.6 \%$ & $11.5 \%$ \\
\hline Sole proprietorships & $11.8 \%$ & $17.9 \%$ & $6.1 \%$ & $9.8 \%$ & $21.4 \%$ & $11.6 \%$ & $8.4 \%$ & $18.7 \%$ & $10.3 \%$ \\
\hline Partnerships & $6.8 \%$ & $9.8 \%$ & $3.0 \%$ & $2.6 \%$ & $17.7 \%$ & $15.1 \%$ & $-0.2 \%$ & $17.0 \%$ & $17.1 \%$ \\
\hline Equipment & $4.0 \%$ & $5.6 \%$ & $1.6 \%$ & $3.4 \%$ & $18.9 \%$ & $15.6 \%$ & $3.1 \%$ & $24.8 \%$ & $21.7 \%$ \\
\hline Structures & $17.8 \%$ & $23.5 \%$ & $5.8 \%$ & $17.7 \%$ & $27.6 \%$ & $9.8 \%$ & $17.8 \%$ & $30.0 \%$ & $12.2 \%$ \\
\hline Residential & $19.4 \%$ & $27.3 \%$ & $7.9 \%$ & $19.5 \%$ & $27.8 \%$ & $8.2 \%$ & $19.8 \%$ & $28.4 \%$ & $8.6 \%$ \\
\hline Intellectual property & $-14.9 \%$ & $-11.2 \%$ & $3.7 \%$ & $-16.1 \%$ & $2.7 \%$ & $18.8 \%$ & $-16.9 \%$ & $2.1 \%$ & $19.0 \%$ \\
\hline All business & $10.0 \%$ & $14.5 \%$ & $4.5 \%$ & $9.7 \%$ & $22.1 \%$ & $12.4 \%$ & $9.6 \%$ & $25.0 \%$ & $15.4 \%$ \\
\hline All business, incl. state/local taxes & $24.8 \%$ & $28.3 \%$ & $3.5 \%$ & $24.5 \%$ & $34.7 \%$ & $10.2 \%$ & $24.4 \%$ & $36.9 \%$ & $12.5 \%$ \\
\hline \multicolumn{10}{|l|}{ EATRs } \\
\hline Domestic & $11.6 \%$ & $15.6 \%$ & $4.1 \%$ & $11.6 \%$ & $16.9 \%$ & $5.3 \%$ & $11.6 \%$ & $20.2 \%$ & $8.6 \%$ \\
\hline Foreign & $14.2 \%$ & $18.9 \%$ & $4.7 \%$ & $14.2 \%$ & $19.8 \%$ & $5.6 \%$ & $14.2 \%$ & $20.4 \%$ & $6.2 \%$ \\
\hline Std.Dev. of cost of capital & $0.93 \%$ & $1.13 \%$ & $0.21 \%$ & $0.93 \%$ & $1.02 \%$ & $0.09 \%$ & $0.94 \%$ & $1.03 \%$ & $0.09 \%$ \\
\hline
\end{tabular}

The baseline has the 2017 tax cuts made permanent. Rates combine federal and state. METTR also includes personal taxes on capital income. 
Table 4. Biden Climate/Energy Proposals

Proposal

Methane limits

ANWR restrictions

No new federal oil and gas leasing

Tighter standards for fuel economy/emissions by passenger vehicles

Carbon pollution-free power sector by 2035

Net zero emissions by 2050

Polluters pay

Clean energy research

Rejoin Paris agreement

Reduce carbon footprint of buildings Climate-related financial risk disclosure

Displaced community aid
Brief Description

Restore limits for oil and gas operations

Permanently protecting Artic National Wildlife Re

Both on shore and offshore

Ensuring $100 \%$ of new sales for light and medium. In order to rely on historical compliance duty vehicles including trucks will be zero emissions

Nuclear generation would continue but no new nuclear capacity

Includes carbon capture.

Reparations owed by businesses that emitted carbon dioxide and other pollutants in the past

\$400 billion over 10 years, including creating ARPA-C

Also includes diplomatic efforts to increase national pledges.

50 percent reduction by 2035 .

Details unspecified

Fulfill obligations to communities and workers invested in coal.
Our model

Part of our estimates of reversing Trump's Obama reversals transactions, we model a less ambitious standard: 80 miles per gallon for passenger vehicles only.

In order to rely on detail estimates by DOE personnel, we assume a less ambitious goal: 20 percent fossil fuel generation by 2050. Subsidies are used to maintain retail prices.

No cost is assessed in this paper, aside from those cited above.

Excise taxes with revenue contributing to the renewable electricity subsidies that maintain retail electricity prices.

No cost assessed, except to the extent financed with the taxes on corps and high-income.

No cost is assessed in this paper. 
Table 5. Costs and quantities of electricity by source

For three policy scenarios.

\begin{tabular}{|c|c|c|c|}
\hline Annual outcome & Baseline & $80 \% \mathrm{RE}$ & Expanded fleet \\
\hline \multicolumn{4}{|l|}{ Renewable sources } \\
\hline Aggregate billion MWh & 0.7 & 2.8 & 3.6 \\
\hline Increment & & 2.1 & 0.8 \\
\hline Marginal cost, $\$ / \mathrm{MWh}$ & 67 & 117 & 136 \\
\hline Subsidy, $\$$ billion & 16 & 202 & 327 \\
\hline \multicolumn{4}{|l|}{ Fossil fuel sources } \\
\hline Aggregate billion MWh & 2.9 & 0.8 & 1.0 \\
\hline Increment & & -2.1 & 0.2 \\
\hline Marginal cost, \$/MWh & 45 & 29 & 30 \\
\hline Tax, \$ billion & 0 & 13 & 15 \\
\hline $\begin{array}{l}\text { Producer surplus, } \$ \text { billior } \\
\text { (difference from baseline) }\end{array}$ & 0 & -30 & -29 \\
\hline
\end{tabular}

Nuclear

Aggregate billion MWh

0.5

$\begin{array}{ll}0.5 & 0.5\end{array}$

All sources

Aggregate billion MWh

4.1

4.1

5.1

Increment

0

1

Resource costs, $\$$ billion

Relative to baseline

0

177

Increment

115

62

Social costs, $\$$ billion

Relative to baseline

115

62

Increment

0

144

214

144

70

Note: Each panel reports metrics for a segment of electricity supply.

The final panel is the aggregate of the others.

Sources: 80\% RE from Mai et al (2014), other outcomes and scenarios from Figure 2. The resource cost for the expanded fleet excludes what the fleet's electricity would cost at baseline fossil MC. 
Table 6. Regulation as tax and productivity wedges

\begin{tabular}{|c|c|c|c|c|c|c|}
\hline \multirow{4}{*}{$\begin{array}{l}\text { Renewable Electricity Generation } \\
\text { Generation capacity for an electric } \\
\text { vehicle fleet }\end{array}$} & \multicolumn{3}{|c|}{$\$$ billion/yr } & \multicolumn{2}{|c|}{ Redistribution as } & \multirow{2}{*}{$\begin{array}{c}\text { Resource cost a } \\
\% \text { of GDP }\end{array}$} \\
\hline & Resource cost & Redistribution & Total cost & $\$$ billions/yr & $\%$ of wages & \\
\hline & 115 & 58 & 144 & 58 & $0.5 \%$ & $0.6 \%$ \\
\hline & 62 & 61 & 93 & 61 & $0.5 \%$ & $0.3 \%$ \\
\hline $80 \mathrm{MPG}$ average for new vehicles & 186 & 0 & 186 & 0 & $0.0 \%$ & $0.9 \%$ \\
\hline Energy-policy total & 363 & 120 & 423 & 120 & $1.0 \%$ & $1.8 \%$ \\
\hline CEA 20 regulations & 0 & 279 & 140 & 279 & $1.9 \%$ & $0.0 \%$ \\
\hline All quantified regulations & 363 & 399 & 563 & 399 & $3.0 \%$ & $1.8 \%$ \\
\hline
\end{tabular}

Note: The table shows the derivation of the additions to labor wedges and Total Factor Productivity (TFP) reported in Table

2. Redistribution contributes to the labor wedge while resource costs reflect reductions in TFP. 
Table 7. Indicators of the Incidence of Proposed Energy Regulation by State

\begin{tabular}{|c|c|c|c|c|c|}
\hline \multirow[b]{2}{*}{ State } & \multicolumn{4}{|c|}{ Value of Proved Reserves (2018, $\$$ billions) } & \multirow{2}{*}{$\begin{array}{l}\text { under } 80 \text { percent } \mathrm{RE} \text { target } \\
\qquad \$ \text { billions }\end{array}$} \\
\hline & Natural Gas & Oil & Coal & Sum & \\
\hline$\overline{\mathrm{AK}}$ & 17 & 151 & 2 & 169 & 29 \\
\hline AL & 4 & 4 & 33 & 41 & 7 \\
\hline AR & 28 & 2 & 7 & 37 & 6 \\
\hline CA & 5 & 156 & - & 162 & 27 \\
\hline $\mathrm{CO}$ & 72 & 102 & 9 & 184 & 31 \\
\hline IL & - & - & 82 & 82 & 14 \\
\hline $\mathrm{IN}$ & - & - & 20 & 20 & 3 \\
\hline $\mathrm{KS}$ & 7 & 20 & - & 27 & 5 \\
\hline KY & 4 & 1 & 40 & 45 & 8 \\
\hline LA & 104 & 32 & 1 & 138 & 23 \\
\hline MI & 4 & 3 & 4 & 11 & 2 \\
\hline MT & 1 & 16 & 29 & 47 & 8 \\
\hline ND & 34 & 355 & 17 & 406 & 69 \\
\hline $\mathrm{NE}$ & - & 1 & 5 & 6 & 1 \\
\hline NM & 72 & 193 & - & 265 & 45 \\
\hline $\mathrm{OH}$ & 90 & 13 & 4 & 106 & 18 \\
\hline $\mathrm{OK}$ & 120 & 156 & 0 & 277 & 47 \\
\hline PA & 315 & 8 & 67 & 390 & 66 \\
\hline TX & 436 & 1,175 & 7 & 1,618 & 275 \\
\hline UT & 9 & 25 & 7 & 40 & 7 \\
\hline WV & 116 & 13 & 125 & 254 & 43 \\
\hline WY & 61 & 72 & 70 & 204 & 35 \\
\hline Other States & 9 & 10 & 13 & 31 & 5 \\
\hline Offshore & 20 & 346 & - & 366 & 62 \\
\hline US & 1,516 & 2,889 & 548 & 4,952 & 841 \\
\hline
\end{tabular}

Note: Producer surplus loss is a present value.

Sources: EIA (2019b), Davis and Cairns (1999), Table 5 
Table 8. Labor wedges from proposed ACA policies

Share Average added MTR, \% points

Policy change

affected Nonzero adder Including zeros

Implicit full-time employment taxes (FTET)

Gold benchmark rather than silver $\quad 0.29$

$\begin{array}{llll}\text { Remove 400\% FPL cap } & 0.15 & 2.0 & 0.3\end{array}$

Public option

0.29

TOTAL implicit FTET

$2.3 \quad 0.6$

Implicit income taxes

$\begin{array}{llll}\text { Gold benchmark rather than silver } & 0.06 & 3.0 & 0.2\end{array}$

Remove 400\% FPL cap

0.0

\section{Income-tax equivalent of all provisions}

Person-weighted average marginal rate

Note: The final column is the product of the previous two.

Sources: Shares affected from Mulligan (2015, Table 4.1) and Kaiser Family

Foundation (2020a,b). The gold addition to the tax credit is based on Mulligan (2015, Table 4.3, Figure 4.2, Table 5.2). The public option is assumed to cut by a third consumers' perceived discount on exchange plans (Mulligan 2015, Table 5.4). $95 \%$ of aggregate hours changes are assumed to be either on the weekly employment margin or on the full/part-time margin. The income-weighted average is based on the labor-quality effect estimated in Mulligan (2015, Table 8.3 ). 
Table 9. Macroeconomic effects of Vice President Biden's Agenda

Full- and partial-agenda scenarios, with effects expressed in per capita terms.

\begin{tabular}{|c|c|c|c|c|c|c|}
\hline & \multirow[b]{2}{*}{$\begin{array}{r}\text { Baseline } \\
\text { values }\end{array}$} & \multicolumn{5}{|c|}{ Scenario impact as $\%$ of baseline } \\
\hline & & Full Agenda & Tax only & $\begin{array}{r}\text { Regulation } \\
\text { only }\end{array}$ & $\begin{array}{r}\text { Capital tax } \\
\text { only }\end{array}$ & $\begin{array}{l}\text { Capital } \\
\text { taxation } \\
\text { constant }\end{array}$ \\
\hline \multicolumn{7}{|l|}{ After-tax shares } \\
\hline Labor & 0.52 & $-7.5 \%$ & $-4.7 \%$ & $-3.0 \%$ & 0 & $-7.5 \%$ \\
\hline Capital & 0.76 & $-16.5 \%$ & $-16.5 \%$ & 0 & $-16.5 \%$ & 0 \\
\hline Normalized TFP & 1 & $-1.7 \%$ & $0.0 \%$ & $-1.8 \%$ & 0 & $-1.7 \%$ \\
\hline \multicolumn{7}{|l|}{ Labor market } \\
\hline Normalized FTEs & 1 & $-3.1 \%$ & $-2.1 \%$ & $-1.0 \%$ & $-0.5 \%$ & $-2.6 \%$ \\
\hline Real wage rates, pre-tax & 0.7 & $-5.6 \%$ & $-3.1 \%$ & $-2.5 \%$ & $-3.2 \%$ & $-2.5 \%$ \\
\hline Labor income & 0.7 & $-8.5 \%$ & $-5.2 \%$ & $-3.5 \%$ & $-3.7 \%$ & $-5.0 \%$ \\
\hline \multicolumn{7}{|l|}{ Capital market } \\
\hline Capital stock & 2.5 & $-15.1 \%$ & $-12.0 \%$ & $-3.5 \%$ & $-10.7 \%$ & $-5.0 \%$ \\
\hline Capital intensity & 2.5 & $-12.4 \%$ & $-10.2 \%$ & $-2.5 \%$ & $-10.2 \%$ & $-2.5 \%$ \\
\hline Gross marginal product & 0.12 & $7.8 \%$ & $7.8 \%$ & 0 & $7.8 \%$ & 0 \\
\hline Net marginal product & 0.048 & $19.7 \%$ & $19.7 \%$ & 0 & $19.7 \%$ & 0 \\
\hline \multicolumn{7}{|l|}{ Aggregates } \\
\hline Real GDP normalized & 1 & $-8.5 \%$ & $-5.2 \%$ & $-3.5 \%$ & $-3.7 \%$ & $-5.0 \%$ \\
\hline Real consumption & 0.82 & $-7.0 \%$ & $-3.7 \%$ & $-3.5 \%$ & $-2.1 \%$ & $-5.0 \%$ \\
\hline
\end{tabular}

Note: Each row is a measure of economic activity, with quantities expressed in per capita terms. Each column is part (or the whole) of the Biden agenda. Each entry is the percentage different between the Biden outcome and the baseline outcome, as projected for the steady state of the neoclassical growth model. The full agenda is calculated from the two bold rows in Table 2. 


\section{Table 10. Sensitivity Analysis}

The full-agenda scenario under alternative assumptions

\begin{tabular}{|c|c|c|c|c|}
\hline & \multicolumn{4}{|c|}{ Full-agenda impact as $\%$ of baseline } \\
\hline & & Nonenvironmental & & \multirow{4}{*}{$\begin{array}{l}\text { More elastic } \\
\text { labor supply }\end{array}$} \\
\hline & & regulations use & & \\
\hline & Benchmark & resources rather than & Less elastic & \\
\hline & assumptions & redistribute & labor supply & \\
\hline \multicolumn{5}{|l|}{ After-tax shares } \\
\hline Labor & $-7.5 \%$ & $-7.5 \%$ & $-7.5 \%$ & $-7.5 \%$ \\
\hline Capital & $-16.5 \%$ & $-16.5 \%$ & $-16.5 \%$ & $-16.5 \%$ \\
\hline Normalized TFP & $-1.7 \%$ & $-3.1 \%$ & $-1.7 \%$ & $-1.7 \%$ \\
\hline \multicolumn{5}{|l|}{ Labor market } \\
\hline Normalized FTEs & $-3.1 \%$ & $-3.1 \%$ & $-1.9 \%$ & $-4.6 \%$ \\
\hline Real wage rates, pre-tax & $-5.6 \%$ & $-7.5 \%$ & $-5.6 \%$ & $-5.6 \%$ \\
\hline Labor income & $-8.5 \%$ & $-10.3 \%$ & $-7.3 \%$ & $-9.9 \%$ \\
\hline \multicolumn{5}{|l|}{ Capital market } \\
\hline Capital stock & $-15.1 \%$ & $-16.8 \%$ & $-14.0 \%$ & $-16.4 \%$ \\
\hline Capital intensity & $-12.4 \%$ & $-14.2 \%$ & $-12.4 \%$ & $-12.4 \%$ \\
\hline Gross marginal product & $7.8 \%$ & $7.8 \%$ & $7.8 \%$ & $7.8 \%$ \\
\hline Net marginal product & $19.7 \%$ & $19.7 \%$ & $19.7 \%$ & $19.7 \%$ \\
\hline \multicolumn{5}{|l|}{ Aggregates } \\
\hline Real GDP normalized & $-8.5 \%$ & $-10.3 \%$ & $-7.3 \%$ & $-9.9 \%$ \\
\hline Real consumption & $-7.0 \%$ & $-8.9 \%$ & $-5.8 \%$ & $-8.5 \%$ \\
\hline
\end{tabular}

Note: Table 10 shows results for Table 9 based on alternative assumptions about the economic effects of regulation and about labor supply. 
Table 11. Capital Tax Wedges under Alternative Scenarios

Comparison of alternative tax systems

\begin{tabular}{|c|c|c|c|c|}
\hline & Current policy & Extend II provisions & Current law & Biden plan \\
\hline \multicolumn{5}{|l|}{ Marginal Effective Tax Rate (METR) } \\
\hline $\mathrm{C}$ corporations & $-5.0 \%$ & $4.7 \%$ & $4.7 \%$ & $7.1 \%$ \\
\hline S corporations & $-4.5 \%$ & $6.1 \%$ & $8.2 \%$ & $7.6 \%$ \\
\hline Sole proprietorships & $-0.3 \%$ & $6.7 \%$ & $8.7 \%$ & $10.2 \%$ \\
\hline Partnerships & $-5.0 \%$ & $10.4 \%$ & $12.3 \%$ & $11.9 \%$ \\
\hline Equipment & $-13.2 \%$ & $5.1 \%$ & $5.3 \%$ & $6.8 \%$ \\
\hline Structures & $5.1 \%$ & $10.7 \%$ & $11.3 \%$ & $13.9 \%$ \\
\hline Residential & $7.8 \%$ & $7.8 \%$ & $9.2 \%$ & $15.2 \%$ \\
\hline Intellectual property & $-33.8 \%$ & $-18.3 \%$ & $-18.3 \%$ & $-20.2 \%$ \\
\hline All business & $-4.6 \%$ & $5.4 \%$ & $5.9 \%$ & $7.8 \%$ \\
\hline All business, incl. state/local taxes & $10.2 \%$ & $19.4 \%$ & $19.6 \%$ & $20.1 \%$ \\
\hline \multicolumn{5}{|c|}{ Marginal Effective Total Tax Rate (METTR) } \\
\hline C corporations & $11.4 \%$ & $19.5 \%$ & $20.4 \%$ & $27.4 \%$ \\
\hline S corporations & $3.1 \%$ & $12.5 \%$ & $14.2 \%$ & $14.6 \%$ \\
\hline Sole proprietorships & $8.4 \%$ & $14.8 \%$ & $16.6 \%$ & $18.7 \%$ \\
\hline Partnerships & $-0.2 \%$ & $14.7 \%$ & $17.1 \%$ & $17.0 \%$ \\
\hline Equipment & $3.1 \%$ & $18.7 \%$ & $19.6 \%$ & $24.8 \%$ \\
\hline Structures & $17.8 \%$ & $22.7 \%$ & $23.8 \%$ & $30.0 \%$ \\
\hline Residential & $19.8 \%$ & $19.8 \%$ & $21.6 \%$ & $28.4 \%$ \\
\hline Intellectual property & $-16.9 \%$ & $-3.1 \%$ & $-1.7 \%$ & $2.1 \%$ \\
\hline All business & $9.6 \%$ & $18.3 \%$ & $19.4 \%$ & $25.0 \%$ \\
\hline All business, incl. state/local taxes & $24.4 \%$ & $32.2 \%$ & $32.6 \%$ & $36.9 \%$ \\
\hline
\end{tabular}

Current policy has the temporary provisions of the 2017 tax law extended and made permanent. The "Extend II provisions" supposes that only the individual income tax provisions of the 2017 tax law are made permanent. Current law allows all phase-outs and expirations of tax provisions under current law to occur. All measures presented are for 2029. 
Figure 1. Share of employment affected by pass-through tax hikes in 2030

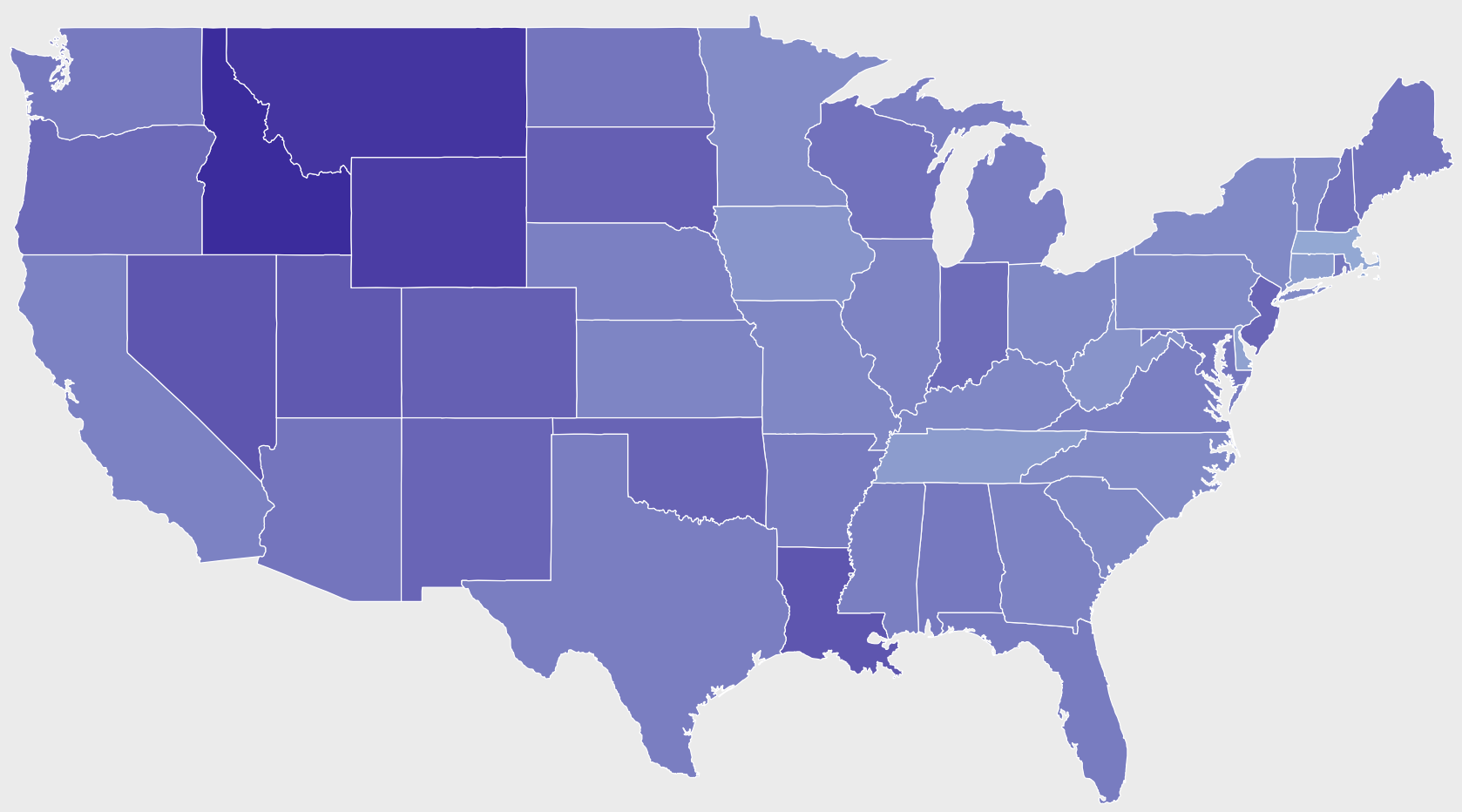

$\%$ affected

55 


\section{Figure 2. The Opportunity Costs of Vehicle Fuel Efficiency}

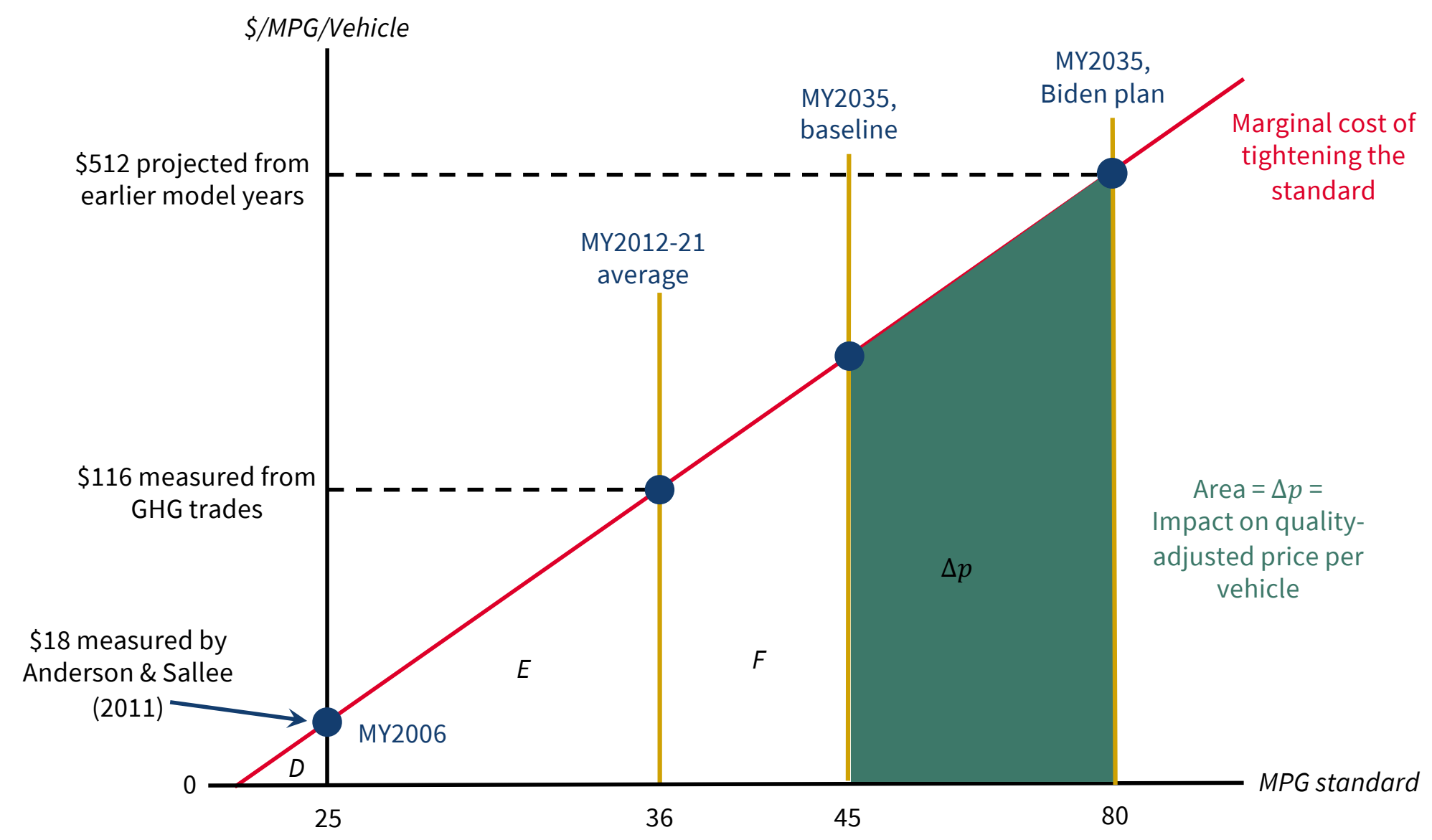

Source: Mulligan (2020) and Anderson \& Sallee (2011). Note that \$116/MPG/Vehicle is equivalent to $\$ 86$ per ton of GHG. 
Figure 3. The Composition of Non-nuclear Electricity Generation $\$$ /MWh

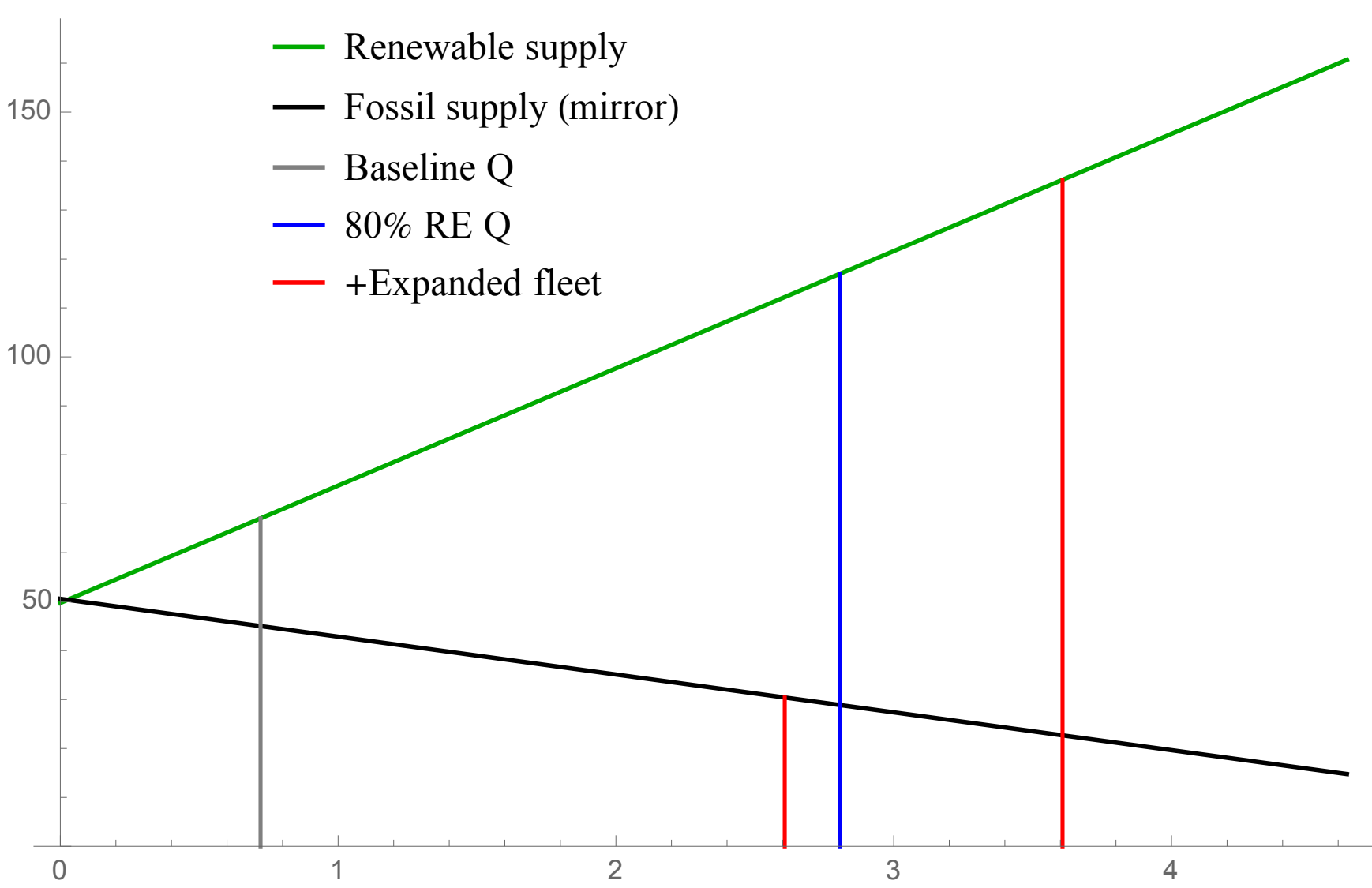

Renewable billion $\mathrm{MWh} / \mathrm{yr}$ 


\section{Bibliography}

Akerlof, George, et al. "We the undersigned..." axios.com. September 22, 2020. https://www.documentcloud.org/documents/7215135-Biden-Econ-Nobel-Letter-09-2220.html.

Anderson, Soren T., and James M. Sallee. "Using loopholes to reveal the marginal cost of regulation: The case of fuel-economy standards." American Economic Review 101 (2011): 1375-1409.

Barro, Robert J., and Jason Furman. "Macroeconomic effects of the 2017 tax reform." Brookings papers on economic activity, 2018: 257-345.

Bellora, Cecilia, and Lionel Fontagné. "Shooting oneself in the foot? Trade war and global value chains." (CEPII working paper) 2019.

Bento, Antonio M., Mark R. Jacobsen, Christopher R. Knittel, and Arthur A. Van Benthem. "Estimating the Costs and Benefits of Fuel-Economy Standards." Environmental and Energy Policy and the Economy 1 (2020): 129-157.

Biden, Joe. "9 Key Elements of Joe Biden's Plan for a Clean Energy Revolution." joebiden.com. 2020. https://joebiden.com/9-key-elements-of-joe-bidens-plan-for-a-clean-energyrevolution/.

Boskin, Michael J., Marc S. Robinson, Terrance O'Reilly, and Praveen Kumar. "New estimates of the value of federal mineral rights and land." The American Economic Review 75 (1985): 923-936.

Brown, Jason P., Timothy Fitzgerald, and Jeremy G. Weber. "Does resource ownership matter? Oil and gas royalties and the income effect of extraction." Journal of the Association of Environmental and Resource Economists 6 (2019): 1039-1064.

Caselli, Francesco, and James Feyrer. "The marginal product of capital." The quarterly journal of economics 122 (2007): 535-568.

Chirinko, Robert S. "Business fixed investment spending: Modeling strategies, empirical results, and policy implications." Journal of Economic literature 31 (1993): 1875-1911.

Congressional Budget Office. "Budget and Economic Data: 10-year Economic Projections." cbo.gov. July 2020. https://www.cbo.gov/data/budget-economic-data\#4.

—. "Taxing Capital Income: Effective Marginal Tax Rates Under 2014 Law and Selected Policy Options." Congressional Budget Office. December 2014.

https://www.cbo.gov/sites/default/files/113th-congress-2013-2014/reports/49817taxingcapitalincome0.pdf.

Council of Economic Advisers. Economic Report of the President. Executive Office of the President, February 2020.

Council of Economic Advisers. Economic Report of the President. Executive Office of the President, March 2019.

Council of Economic Advisers. The Value of U.S. Energy Innovation and Policies Supporting the Shale Revolution. Executive Office of the President, October 2019.

Crandall, Robert W. "Policy watch: corporate average fuel economy standards." Journal of Economic Perspectives 6 (1992): 171-180.

Davis, Graham A., and Robert D. Cairns. "Valuing petroleum reserves using current net price." Economic Inquiry 37 (1999): 295-311.

Dennis, Brady, and Dino Grandoni. "How Joe Biden’s surprisingly ambitious climate plan came together." Washington Post, August 1, 2020. 
Devereux, Michael P., and Rachel Griffith. "Evaluating tax policy for location decisions." International tax and public finance 10 (2003): 107-126.

Elliston, Ben, Jenny Riesz, and Iain MacGill. "What cost for more renewables? The incremental cost of renewable generation-An Australian National Electricity Market case study." Renewable Energy 95 (2016): 127-139.

Epstein, Jennifer. "Biden Urges Diverse Fed to Fight Racial Economic Inequality." Washington Post, July 29, 2020.

Federal Reserve Bank of St. Louis. "Series GDP, IMPGS, COE, NICUR, PROPINC, B102RC1Q027SBEA, GDPDEF, PAYEMS, MEHOINUSA646N." Federal Reserve Economic Data. 2020. http://research.stlouisfed.org/fred2/ (accessed September 2020).

Fitzgerald, Timothy, and Randal R. Rucker. "US private oil and natural gas royalties: estimates and policy relevance." OPEC Energy Review 40 (2016): 3-25.

Hall, Robert E., and Dale W. Jorgenson. "Tax policy and investment behavior." The American Economic Review 57 (1967): 391-414.

Handley, Kyle, and Nuno Limao. "Policy uncertainty, trade, and welfare: Theory and evidence for China and the United States." American Economic Review 107 (2017): 2731-83.

Hassett, Kevin A., and Gilbert E. Metcalf. "Investment with uncertain tax policy: Does random tax policy discourage investment." The Economic Journal 109 (1999): 372-393.

Hassett, Kevin. "Tax Policy and the Economy: An Early Look at the Economic Impact of TCJA." Special Session of the Annual Meeting. American Economic Association, 2019.

Heal, Geoffrey. "Economic Aspects of the Energy Transition." NBER working paper no. 27766 (September 2020).

Henry J. Kaiser Family Foundation. "Distribution of the Nonelderly with Employer Coverage by Federal Poverty Level (FPL)." kff.org. 2020. https://www.kff.org/private-insurance/stateindicator/distribution-by-fpl-3/ (accessed September 2020).

—. "Marketplace Enrollment, 2014-2020." kff.org. 2020. https://www.kff.org/healthreform/state-indicator/marketplace-enrollment/ (accessed September 2020).

Holland, Stephen P., Erin T. Mansur, Nicholas Z. Muller, and Andrew J. Yates. "Are there environmental benefits from driving electric vehicles? The importance of local factors." American Economic Review 106 (2016): 3700-3729.

Holland, Stephen P., Erin T. Mansur, Nicholas Z. Muller, and Andrew J. Yates. "Distributional effects of air pollution from electric vehicle adoption." Journal of the Association of Environmental and Resource Economists 6 (2019): S65-S94.

Ikenson, Daniel J. "Who Is Paying for Trump’s Tariffs?" cato.org. February 27, 2020. https://www.cato.org/blog/whos-bearing-burden-tariff-boom.

Jaffe, Sonia, Robert Minton, Casey B. Mulligan, and Kevin M. Murphy. Chicago Price Theory. Princeton University Press (chicagopricetheory.com), 2019.

Jorgenson, Dale. The economics of productivity. Edward Elgar Publishing, 2009.

Lawrence Berkeley National Laboratory. "U.S. Renewable Portfolio Standards 2018 Annual Status Report." lbl.gov. November 2018. http://etapublications.lbl.gov/sites/default/files/2018_annual_rps_summary_report.pdf.

Levinson, Brian. "Cost Benefit Analysis of Cafe Standards compared to the Alternative Fuel/Carbon Tax." Journal of Environmental and Resource Economics at Colby 2 (2015): 126.

Mai, Trieu, David Mulcahy, M. Maureen Hand, and Samuel F. Baldwin. "Envisioning a renewable electricity future for the United States." Energy 65 (2014): 374-386. 
Mai, Trieu, et al. "The role of input assumptions and model structures in projections of variable renewable energy: A multi-model perspective of the US electricity system." Energy Economics 76 (2018): 313-324.

McLaughlin, Patrick, and Casey B. Mulligan. "Three Myths about Federal Regulation." NBER working paper, no. 27233 (May 2020).

Mulligan, Casey B. "Capital, Interest, and Aggregate Intertemporal Substitution." NBER working paper, no. 9373 (December 2002).

Mulligan, Casey B. Side Effects and Complications: The Economic Consequences of Health-care Reform. Chicago: University of Chicago Press, 2015.

—. The Redistribution Recession. New York: Oxford University Press (redistributionrecession.com), 2012.

—. You're Hired! Untold Successes and Failures of a Populist President. Alexandria, VA: Republic Book Publishers, 2020.

New Climate Institute. "Pledges and Targets." climateactiontracker.org. September 2020. https:/climateactiontracker.org/countries/usa/pledges-and-targets/.

Newell, Richard G., and Brian C. Prest. "The unconventional oil supply boom: Aggregate price response from microdata." The Energy Journal (International Association for Energy Economics) 40 (2019).

Newell, Richard G., Brian C. Prest, and Ashley B. Vissing. "Trophy hunting versus manufacturing energy: The price responsiveness of shale gas." Journal of the Association of Environmental and Resource Economists (University of Chicago Press Chicago, IL) 6 (2019): 391-431.

Office of Management and Budget. "Circular A-4: Regulatory Analysis." (OMB, Office of Information and Regulatory Affairs) 2003.

—. "President's Budget." whitehouse.gov. February 2020. https://www.whitehouse.gov/omb/budget/.

Pomerleau, Kyle. "An Overview of Pass-through Businesses in the United States." taxfoundation.org. 2015. https://files.taxfoundation.org/legacy/docs/TaxFoundation_SR227.pdf.

Pomerleau, Kyle. The tax burden on business investment under Joe Biden's tax proposals. Washington, DC: American Enterprise Institute, 2020.

Ramey, Valerie A. "Identifying Government Spending Shocks: It’s All in the Timing." Quarterly Journal of Economics 126, no. 1 (March 2011): 1-50.

Summers, Lawrence $\mathrm{H}$. "One last time on who benefits from corporate tax cuts." The Washington Post 22 (October 2017).

United States Census Bureau. "County Business Patterns." census.gov. 2019. https://www.census.gov/programs-surveys/cbp/data/tables.html.

—. "Full-time, year-round workers and median earnings in the past 12 months by sex and detailed occupation: 2013." census.gov. March 16, 2015. https://www2.census.gov/programs-surveys/demo/tables/industry-occupation/timeseries/median-earnings-2013-final.xlsx.

United States Department of the Interior. "Natural Resources Revenue Data." revenuedata.doi.gov. 2020.

United States Energy Information Administration. "2019 Annual Energy Outlook." eia.gov. 2019a. https://www.eia.gov/outlooks/archive/aeo19/pdf/aeo2019.pdf. 
—. "U.S. Energy Flow, 2018." eia.gov. 2019b. https://www.eia.gov/totalenergy/data/monthly/pdf/flow/total_energy.pdf.

United States Government, Interagency Working Group on Social Cost of Greenhouse Gases. "Technical Support Document Social Cost of Carbon for Regulatory Impact Analysis Under Executive Order 12866." Technical Support Document, 2010.

United States Government, Interagency Working Group on Social Cost of Greenhouse Gases. "Technical Update of the Social Cost of Carbon for Regulatory Impact Analysis Under Executive Order 12866." Technical Support Document, 2016.

United States Internal Revenue Service. "Table 1.3: All Returns: Sources of Income, Adjustments, Deductions, Credits, and Tax Items." irs.gov. July 2015. https://www.irs.gov/pub/irs-soi/13in13ms.xls.

Viard, Alan D. "The Pitfalls of Temporary Corporate Tax Rate Cuts." Tax Notes 156 (2017).

West, Sarah E., and Roberton C. III Williams. "The cost of reducing gasoline consumption." American Economic Review 95 (2005): 294-299.

Williams, Noah. "Why Joe Biden’s tax plan will bring on a more sluggish US economy." New York Post, August 29, 2020. 